\title{
Thriving or Surviving? Raising Our Ambition for Trans Children in Primary and Secondary Schools
}

\author{
Cal Horton* \\ Education Department, Goldsmiths University, London, United Kingdom
}

As more trans children find the confidence to make themselves known in our primary and secondary schools, school teachers and administrators look for guidance on how to best support trans pupils. This article synthesises findings from global literature on trans children in primary and secondary education (K1-12 in the US), extracting key themes and conclusions. It then examines the most recent UK school guidance documents on trans inclusion, assessing which lessons and recommendations from global literature are represented. The article highlights existing good practices in visibility and representation and in protection from violence and harassment. Several areas where additional effort

OPEN ACCESS

Edited by:

Samuel Oliver James Stones, Leeds Beckett University, United Kingdom

Reviewed by: Jorge Gato,

University of Porto, Portugal Jonathan Glazzard,

Leeds Beckett University, United Kingdom Giulio D'Urso,

Kore University of Enna, Italy

*Correspondence: Cal Horton c.horton@gold.ac.uk

Specialty section: This article was submitted to Gender, Sex and Sexualities,

a section of the journal Frontiers in Sociology

Received: 31 May 2020

Accepted: 27 July 2020

Published: 11 August 2020

Citation:

Horton C (2020) Thriving or Surviving? Raising Our Ambition for Trans Children in Primary and Secondary

Schools. Front. Sociol. 5:67. doi: 10.3389/fsoc.2020.00067 is needed are identified, including action on environmental stress and cisnormativity, addressing barriers to school trans-inclusivity and institutional accountability. A number of important shifts are called for: from adaptation on request to pre-emptive change; from accommodation to a rights-based approach; from pathologisation to trans-positivity. Finally, the article raises expectations on what it means to be an ally for trans children in education.

Keywords: trans, transgender, child, school, education, youth, primary, secondary

\section{INTRODUCTION}

The twenty-first century has seen a global movement away from pathologisation of gender diversity (Bryant, 2006, 2007; Ehrensaft, 2012; Menvielle, 2012; Spack et al., 2012). Gender affirmative approaches to supporting trans children are becoming mainstream (Hidalgo et al., 2013; CASW ACTS, 2015; Ehrensaft, 2016; Murchison et al., 2016; Lopez et al., 2017; Oliphant et al., 2018; Rafferty et al., 2018; Turban and Ehrensaft, 2018). This shift toward gender affirmative approaches is underpinned by evidence of the damage to trans children caused by childhood abuse and rejection, including the harm of conversion therapy (Roberts et al., 2012; Ashley, 2019b; Turban et al., 2019).

There is now strong evidence that socially transitioned children who are supported have good levels of well-being and mental health (Ehrensaft, 2016; Olson, 2016; Durwood et al., 2017; Ehrensaft et al., 2018). Factors associated with improved well-being in trans children include family functioning (Katz-Wise et al., 2018), family support (Travers et al., 2012; Simons et al., 2013; Klein and Golub, 2016), and use of chosen name (Russell et al., 2018). Informed by global healthcare best practices (Oliphant et al., 2018) trans children are increasingly likely to receive love and support in childhood (Ehrensaft, 2016), including transitions at or before primary school (Miller, 2016a; Davy and Cordoba, 2019). Many trans children are aware of their identity at a young age (Jones and Hillier, 2013; Telfer et al., 2015; Fast and Olson, 2018) meaning a majority of educators will at some point work with trans pupils, although teachers may not be aware of the trans children 
in their classroom (Rands, 2009; Meyer and Leonardi, 2018). Educators can look to a variety of trans inclusion school guidance documents to shape their support for trans pupils of all ages. It is important that these guidance documents are informed by the most up to date literature on trans children. This paper aims to review whether best practices from research literature on trans children in education is feeding through into guidance on supporting trans children in our schools.

Until recently, trans children have been almost invisible in both academic literature and public consciousness, with gender diversity problematised and hidden (Brill and Pepper, 2008; Gill-Peterson, 2018). A majority of older literature on trans children was pathologising and cisnormative ${ }^{1}$ (Ansara and Hegarty, 2012). There has been a recent growth in trans positive research on trans children, looking at the identities of young trans children (Olson et al., 2015; Olson, 2016; Fast and Olson, 2018; Olson and Enright, 2018; Olson and Gülgöz, 2018; Rae et al., 2019; Pullen Sansfaçon et al., 2020), reflecting on social transition (Turban, 2017; Whyatt-Sames, 2017; Turban and Keuroghlian, 2018; Ashley, 2019a,c), and trans children's experiences in education (Bartholomaeus and Riggs, 2017a). Research is now examining the external challenges experienced by trans children and families (Capous-Desyllas and Barron, 2017; Alegría, 2018), including the impact discrimination, and structural cisnormativity $^{2}$ (Hendricks and Testa, 2012; McBride, 2020). This builds upon wider work on the Minority Stress Model (Meyer, 2003); the ways in which experiences of prejudice, stigma and discrimination negatively impact on mental health. Modern, trans-positive research on trans children in education looks at cisnormativity and the structural and systemic barriers to trans children having equality of opportunity in our schools (Bartholomaeus and Riggs, 2017a; McBride, 2020).

In this paper the term "trans children" will be used. Trans children includes transgender and or non-binary children, also described as "gender diverse children" (Keo-Meier and Ehrensaft, 2018). "Cis" is a term for non-trans or cisgender people. Where all ages under 18 are included (including the youngest preprimary and primary school children) the term children will be used. Where necessary this will be divided either into trans children and trans adolescents and where appropriate the term trans young people or trans youth will be used, with the term youth excluding younger children and including young adults (UNDESA, 2013).

A trans-emancipatory approach informs this research, aiming to proactively avoid pathologisation or cisnormativity, recognising the rights of trans children to equality of opportunity in education. Additional research standards are needed for

\footnotetext{
${ }^{1}$ Cisnormativity is the assumption that everyone is cisgender or should be (KeoMeier and Ehrensaft, 2018). Serano talked about the concept as a societal doublestandard that conveys social and legal legitimacy on cis people's identities, with cis identities "taken for granted and considered valid in a way that trans people's are not", providing cis people with an advantage (Serano, 2011, 29).

${ }^{2}$ Structural cisnormativity exacts disproportionate harms on trans people, threatening their health, reducing their security and limiting their opportunities (Newbury, 2013). Daily, unpredictable, distressing encounters with structural cisnormativity, leaves trans people in a "constant state of alert" that "manifests as a persistent level of stress unknown to their cis counterpart" (Newbury, 2013, 2).
}

research on trans communities "because of a long history of intolerance, bias, and psychopathological stereotyping in this specialty" (ITHF, 2019, 1). Vincent (2018) outlines six categories to consider when working on trans-related research including nuanced language use and recognising trans histories. Ethical research needs to consider and address the long and continuing pathologisation of trans children, including past and continuing rights violations, producing research that respects the needs and rights of trans children in education today.

I write this as a parent of a trans child of primary school age and an advocate for trans children's rights. Our trans children are brilliant and spectacular and ordinary-in many ways they are exactly the same as their cis classmates. Yet too often trans children are failed by our cisnormative systems and priorities, too often these children face prejudice and ignorance, too often they shoulder the burden of educating the adults around them. Past generations of trans children have been abused and harmedlessons need to be learnt today, to build a better world for tomorrow's trans children.

\section{RESEARCH QUESTIONS AND METHODS}

This paper comprises two strands, responding to two sequential research questions.

1. What are key themes, findings, and recommendations from research literature on trans children in education?

2. Which of these research driven themes, findings, and recommendations are being prioritised in trans-related school policy and guidance documents?

These research questions are timely for a UK audience, as schools move toward LGBT inclusive primary school Relationships Education (Department of Education, 2019). These research questions are also timely globally, in a period where trans inclusive education is under threat in countries across the world, from anti trans legislation targeting trans children in the US, through to toxic political and media driven debates on trans inclusive education in Australia, Canada and beyond (Bartholomaeus and Riggs, 2017a).

Part one of the research involved an extensive review of global literature on trans children in education. Databases including Educational Research Abstracts Online, Education Research Information Center (ERIC), and Web of Science were searched using paired key words including: transgender*/trans* and school*, reviewing articles published between 2005 and 2020 inclusive. An in-depth review of article bibliographies supplemented through researcher expertise enabled identification of additional articles (McBride, 2020). Inclusion criteria on literature type were kept broad to include grey literature studies, and to include commentary, review and analysis articles. Only articles published in English were included, and only articles relating to primary and secondary education, with articles on tertiary education excluded. This search identified articles that provide quantitative or qualitative insights on trans pupils' experience in education, looking at literature on trans children under 18, with literature from the 
TABLE 1 | List of trans-inclusion school resources.

\begin{tabular}{|c|c|}
\hline $\begin{array}{l}\text { Brighton (Brighton and Hove City } \\
\text { Council, 2019) }\end{array}$ & Trans inclusion schools toolkit \\
\hline $\begin{array}{l}\text { CofE (Church of England } \\
\text { Education Office, 2019) }\end{array}$ & $\begin{array}{l}\text { Valuing all god's children: guidance for } \\
\text { Church of England schools on challenging } \\
\text { homophobic, biphobic, and transphobic } \\
\text { bullying }\end{array}$ \\
\hline $\begin{array}{l}\text { EANI (Education Authority } \\
\text { Northern Ireland, 2019) }\end{array}$ & $\begin{array}{l}\text { Guidance for schools, EOTAS Centres and } \\
\text { youth service on supporting transgender } \\
\text { young people }\end{array}$ \\
\hline Equaliteach (Equaliteach, 2020) & $\begin{array}{l}\text { Free to be: embedding lgbt+ equality and } \\
\text { tackling homophobic, biphobic, and } \\
\text { transphobic bullying in primary schools }\end{array}$ \\
\hline Leeds (Leeds City Council, 2018) & $\begin{array}{l}\text { Guidance on supporting children and young } \\
\text { people who are trans or who are questioning } \\
\text { their gender identity for all schools and } \\
\text { children and families services settings }\end{array}$ \\
\hline $\begin{array}{l}\text { LGBT Youth Scotland (LGBT } \\
\text { Youth Scotland, 2017) }\end{array}$ & $\begin{array}{l}\text { Supporting transgender young people: } \\
\text { guidance for schools in Scotland }\end{array}$ \\
\hline $\begin{array}{l}\text { NEU (National Education Union, } \\
\text { 2018) }\end{array}$ & $\begin{array}{l}\text { Supporting trans and gender-questioning } \\
\text { students }\end{array}$ \\
\hline $\begin{array}{l}\text { Orthodox Jewish Schools (Chief } \\
\text { Rabbi Ephraim Mirvis, 2018) }\end{array}$ & $\begin{array}{l}\text { The wellbeing of LGBT Pupils a guide for } \\
\text { orthodox jewish schools }\end{array}$ \\
\hline Stonewall BPG (Stonewall, 2018) & $\begin{array}{l}\text { Best practice guide: how primary schools are } \\
\text { celebrating difference and tackling } \\
\text { homophobia, biphobia and transphobia }\end{array}$ \\
\hline $\begin{array}{l}\text { Stonewall Next Steps (Stonewall, } \\
\text { 2020) }\end{array}$ & Next steps in inclusive education \\
\hline $\begin{array}{l}\text { Stonewall Primary (Stonewall, } \\
\text { 2019) }\end{array}$ & $\begin{array}{l}\text { Creating an LGBT-inclusive primary } \\
\text { curriculum }\end{array}$ \\
\hline $\begin{array}{l}\text { Trans Inclusion Toolkit (Trans } \\
\text { Inclusion Toolkit, 2019) }\end{array}$ & Trans inclusion toolkit for schools \\
\hline
\end{tabular}

last 5 years prioritised. All identified literature was coded using Nvivo software, identifying themes related to trans children's experiences in education. Eight main themes emerged and these are presented in the literature review section.

Part two of the research analysed a selection of guidelines on trans inclusion in education, examining the degree to which themes from the literature review were profiled in the school guidance documents. Relevant primary and or secondary school guidance documents were identified, selecting those which made specific reference to trans inclusion. This included guides on trans children, trans young people, LGBT young people or guides on HBT (Homophobic, Biphobic, Transphobic) bullying. School guidance documents published prior to 2017 were excluded; the most recently released or updated guides were prioritised. Whilst part one took a global overview of literature on trans children in education, part two narrowed the scope to UK school guidance documents-though the findings here are likely to have relevance for educators interested in supporting trans children in any country.

Twelve guidance documents were selected for review, and these are listed in Table $\mathbf{1}$ below. One guide that is actively transphobic ${ }^{3}$ was excluded. The review did not aim to provide a

$\overline{{ }^{3} \text { See https://www.stonewall.org.uk/node/62946 }}$ forensic analysis of any specific guide, but rather to see how well key themes from the literature are represented in school guidance documents. Several of these guides were produced by civil society organisations. Two were from religious organisations (Church of England and Jewish Orthodox). Several were produced by English councils, two were associated with regional devolved government and one was produced by the National Education Union. The 2019 Trans Inclusion Toolkit produced by multiple English Councils is currently facing challenge from groups opposed to trans equality, and later versions of this toolkit currently being revised by local authorities may be significantly different to the 2019 version reviewed here. Notably missing from this list is any England and Wales government endorsed resource, though guidance from the Equalities and Human Right Commission for England Scotland and Wales is anticipated.

\section{GLOBAL LITERATURE REVIEW ON TRANS CHILDREN IN EDUCATION}

This section highlights eight themes derived from a systematic analysis of global literature on trans children's experience in education. The themes include (1) Pathologisation and victim narratives (2) Discrimination and violence (3) Environmental stress and cisnormativity (4) Individual accommodation on request (5) From school panic to affirmation and representation (6) Teacher barriers to action (7) Ambition and allies (8) Child voice and child rights. These themes and findings should shape the ways in which schools support their trans pupils, acknowledging the weaknesses of the current literature including limited consideration of non-binary children, and limited consideration of intersectionality.

\section{Pathologisation and Victim Narratives}

There is a long history of pathologisation, misgendering and invalidation of trans children that cuts across all spheres of society including our schools (Frohard-Dourlent, 2018; GillPeterson, 2018). Ansara and Hegarty (2012, 152) highlight the ways in which pathologising or cisnormative language can "dehumanize, silence and erase." This pathologisation directly affects trans children's experience in school. Riggs and Bartholomaeus (2018) provides an example of a parent of a 5 year old trans girl being asked by a school to provide a psychiatrist report and have genetic testing before the school might accept her. Pathologising approaches can also be expressed in more subtle ways which nevertheless erase and delegitimise (FrohardDourlent, 2018), such as when trans children's identities are denied, or replaced with pathologising and delegitimising terms. The avoidance of the word trans when referring to trans children is a form of erasure, that denies trans children "self-intelligibility" (Kennedy, 2018, 135).

There is a tradition of stigmatization and problematisation of trans children (Pyne, 2014; Kennedy, 2018) with trans children defined through their association with trauma (Marx et al., 2017). Educators also need framings that centre joy, romance, laughter, strength, and resilience (Marx et al., 2017; Shelton and Lester, 2018). Trans pupils, living in cisnormative environments, may 
develop particular strengths, types of cultural capital (Pennell, 2016a). This can include navigational capacity, being able to navigate through systems not designed for trans pupils; linguistic capacity, challenging linguistic norms that marginalise, erase or other trans pupils; familial capacity, finding support from trans peers, trans communities and trans-led narratives; and resistant capital, being able to fight against discrimination and advocate for equality (Pennell, 2016b).

Descriptions of trans children and youth often centre a victim narrative (DePalma and Jennett, 2010), framing them as in need of protection (Marx et al., 2017). This singular and simplistic framing as "at risk" (Frohard-Dourlent, 2018) homogenises, pathologises and others trans youth as inherently separate from healthy cis peers (Miller, 2016c; Marx et al., 2017; Blair and Deckman, 2019). A victim framing also individualises the challenges trans pupils face (Shelton and Lester, 2018), overlooking the structural inequalities harming them (Smith and Payne, 2016).

\section{Discrimination and Violence}

Trans children face multiple areas of overt discrimination, including segregation and denial of access to appropriately gendered spaces (Kennedy, 2013; Kosciw and Pizmony-Levy, 2016; O’Flynn, 2016; UNESCO, 2016; Kuvalanka et al., 2019; Neary, 2019). School-based anti-trans discrimination targeting trans pupils of all ages is apparent in a number of surveys, with trans pupils prevented from using their name or pronoun at school, and forced to use inappropriately gendered facilities (Kosciw et al., 2016, 2018). Harm is compounded when schools enable trans children to be drawn into public debates on whether schools should actively discriminate against trans pupils (Herriot et al., 2018; Miller et al., 2018; Sinclair-Palm and Gilbert, 2018).

Evidence from diverse locations continues to show trans pupils experiencing hostile school climates (Greytak et al., 2009; Grant and Zwier, 2011; Taylor and Peter, 2011; Kosciw et al., 2012, 2016, 2018; Peter et al., 2016; Ullman, 2017; Fayles, 2018; Human Rights Campaign, 2018) with high incidences of verbal harassment, bullying, physical abuse, and sexual harassment (Reed et al., 2010; Human Rights Campaign, 2014, 2018; Kosciw et al., 2016; Peter et al., 2016; Bradlow et al., 2017). Kosciw et al. (2018) found a steady increase in negative remarks about trans people in schools between 2013 and 2017, highlighting that progress is neither linear nor guaranteed. Trans pupils report lack of safety across multiple locations, including in primary schools (Meyer et al., 2016) especially in gendered spaces like changing rooms and bathrooms (Kosciw et al., 2016, 2018). In a 2017 US survey of over 5,000 trans adolescents, only $16 \%$ reported that they always feel safe at school (Human Rights Campaign, 2018).

A hostile school climate can have extensive consequences for trans pupils' ability to thrive (Greytak et al., 2009). Trans pupils experiencing harassment and transphobia are less likely to be able to concentrate in class (Robinson et al., 2014), have lower educational aspirations and poorer educational attainment (Greytak et al., 2009; Kosciw et al., 2012; Robinson et al., 2014; Fayles, 2018). Trans pupils report hiding at lunch times, avoiding gendered spaces like bathrooms and changing rooms (Jones and Hillier, 2013; Robinson et al., 2014), and not participating in extra-curricular events and activities due to lack of safety (Jones and Hillier, 2013; Kosciw et al., 2016). Trans youth have high levels of school absenteeism due to harassment (Greytak et al., 2009, 2013; Taylor and Peter, 2011; Kosciw et al., 2012, 2016; Robinson et al., 2014). Lack of affirmative or safe school environments is also associated with trans pupils dropping out of education or transferring schools (McGuire et al., 2010; O’Flynn, 2016).

In-school victimization and harassment are known to have significant psychological and social consequences (Poteat and Espelage, 2007), including negatively affecting psychological well-being (Kosciw et al., 2012), and contributing to high levels of depression, self-harm, and suicidal ideation (Jones and Hillier, 2013). In a 2017 UK survey of around 500 trans pupils aged 11-19, 45\% reported that they had attempted to take their own life, and 84\% reported self-harm (Bradlow et al., 2017). A negative school climate (combined with wider systemic oppression), leaves trans pupils with low levels of optimism about their chances of future success and happiness (Human Rights Campaign, 2014).

\section{Environmental Stress and Cisnormativity}

Cisnormative school climates place trans pupils under persistent psychological stress (Ullman, 2015b; Miller, 2016c; McBride, 2020). Institutionalised cisnormativity (Bauer et al., 2009) negatively affects trans pupils, delegitimising their identities and making their lives harder in multiple and systemic ways (Miller, 2016c; McBride, 2020). Trans pupils experience persistent microaggressions which they recognize as symptoms of deeply embedded structural inequality and violence (Woolley, 2017), yet schools are likely to view them as individual isolated acts. Schools may already be aware of overt, individualised, intentional acts of transphobia or violence, but they need to also be aware of the compounding effects of subtler acts of cisnormativity, including systemic practices that are not intended to cause harm to trans pupils (Riggs and Bartholomaeus, 2018). Beyond physical safety, trans pupils need to feel emotionally safe and welcome in school (Brill and Pepper, 2008). In the words of one parent of a young primary school aged trans child (Slesaransky-Poe et al., 2013, 30):

"I needed to know if he would be physically and emotionally safe; feel welcomed, respected, and fully embraced; and be able to focus on learning."

A persistently stressful and hostile school climate can make school about survival rather than success and fulfilment (Miller, 2016c), with environmental stressors detrimentally affecting educational achievement and well-being (Ullman, 2017). The educational disadvantage trans youth experience is not individualised, but structural and systemic (McBride, 2020). Trans pupils experiencing macro and micro aggressions (Miller, 2016a) are forced to develop defensive strategies (Greytak et al., 2013; Bowers et al., 2015; Ingrey, 2018; Kennedy, 2018) which are emotionally and cognitively difficult, reducing well-being and the ability to learn and thrive.

Areas of gender segregation can increase the stress felt by trans pupils (Greytak et al., 2013; Kennedy, 2013; Bowers et al., 
2015; Ingrey, 2018), placing them under additional surveillance and pressure to conform (Woolley, 2017). Socially transitioned children who have not disclosed their gender modality-that they are trans-carry an additional stress (McGuire et al., 2010) as they navigate systems which assume they are cis $^{4}$.

Approaches that prioritise an individualised anti-bullying discourse, including the UK Government's approach (Carlile, 2019), overlook the systemic nature of the challenge faced by trans children in schools (Ansara and Hegarty, 2012), and distract from the systemic reforms needed to ensure trans children are welcomed as equals at school (Frohard-Dourlent, 2018; Riggs and Bartholomaeus, 2018). We need to move beyond an exclusive focus on safety, on violence and on individual bullies and victims, to understanding and dismantling the systemic operation of cisnormativity in our schools (Payne and Smith, 2014; Miller, 2016c; Frohard-Dourlent, 2018).

\section{Individual Accommodation on Request}

Few schools provide trans-inclusive adaptations prior to having a known trans pupil (Davy and Cordoba, 2019). Many schools only take reactive actions to accommodate a trans pupil on request (Omercajic, 2015; Davy and Cordoba, 2019), often prompted by informed parent advocacy for their trans child (Neary and Cross, 2018; Riggs and Bartholomaeus, 2018; Davy and Cordoba, 2019). Schools often only accommodate access to appropriate bathrooms after pupils or parents request such access (Ingrey, 2018). This approach means trans pupils' access is to be requested, negotiated and permitted. Ingrey (2018) highlights the rights violation of requiring trans pupils to apply for access, rather than the system proactively making trans pupils welcome. Trans pupils are "subjected to an approval process for a simple act of accessing a suitable washroom space; this process is humiliating, pathologising and alienating, and ultimately transphobic" (Ingrey, 2018, 781).

A individualised "accommodation on request" approach leaves the status quo intact, maintaining an "artificial hierarchy" (Serano, 2016, 13) where the dominant gender (Ingrey, 2018) is validated as "natural," in the process pathologising trans pupils' gender modality (that they are trans-Ashley, 2019d) as requiring approval and exception from the "norm." Trans pupils' right to identity and basic dignity is dependent on them submitting themselves to a pathologising and daunting process of justifying their needs and their identity to cis teachers or school administrators (Ingrey, 2018). This accommodation may be particularly hard for children who are gender fluid or nonbinary (Omercajic and Martino, 2020) - though it needs to be noted that the current literature has little consideration of nonbinary children (Airton and Koecher, 2019).

Meyer and Leonardi (2018) conducted interviews with teachers, which found reluctance to make trans-affirmative school changes unless, and until, they personally knew a trans pupil. This is born out in the wider literature, with numerous examples of schools only making changes when forced to do so, when they encountered their first known trans pupils (Slesaransky-Poe et al., 2013; Mitchell et al., 2014; Baldwin,

${ }^{4}$ Cisitude — the state of being cis — the antonym of transitude (Ashley, 2018)
2015; McBride, 2020). These pioneer children may "shoulder an immense responsibility as singular sites of all learning and change," becoming "sacrificial lambs" (Meyer et al., 2016, 9), whose privacy and right to equality of education are neglected in order for the school to commence incremental adaptation. Meyer et al. $(2016,9)$ discuss the "ethical dilemma of this pedagogy of exposure," and how to prompt trans inclusive school changes without a trans pupil or family being required to expose themselves as educator of an unprepared school.

Supportive parents and carers are relied upon to advocate for their trans children (Neary, 2019), educating their children's teachers, and advising on inclusive policies and curricula (Bartholomaeus and Riggs, 2017a). Families of trans children cannot just presume their children will be safe and welcomed in schools, and instead need to be constantly vigilant, to protect and advocate for their children (Hill and Menvielle, 2009; Johnson et al., 2014; Pullen Sansfaçon et al., 2015; Rahilly, 2015; Riggs and Bartholomaeus, 2018; Neary, 2019). Parental advocacy on behalf of trans children is an ongoing requirement, with support for trans inclusivity not automatically sustained or replicated across a school (Johnson et al., 2014; Riggs and Bartholomaeus, 2018). Effective inclusion needs to be embedded in clear transaffirmative policies and procedures (Bartholomaeus and Riggs, 2017a), which are developed proactively, rather than enacted upon request (Baldwin, 2015).

An individualised approach-listening to a child's voice, hearing their needs and being guided by a child's own individual path-is absolutely critical to child-centred care (Whyatt-Sames, 2017). Where families are supportive of their trans child, a collaborative trusting relationship between families and schools can help ensure an effective child-focused path to providing a friendly, welcoming school (Slesaransky-Poe et al., 2013). However, this individualised approach should not be a way of shifting responsibility onto pupils (Frohard-Dourlent, 2018) and is not a substitute for proactive structural changes to ensure trans children are made welcome in our schools (Omercajic and Martino, 2020). Frohard-Dourlent (2018) imagines a future where trans pupils don't need to self-advocate, because schools are already set up to recognise their existence.

\section{From School Panic to Affirmation and Representation}

There is a pervasive culture of silence (Ullman, 2014; Ullman and Ferfolja, 2015; Frohard-Dourlent, 2016); around trans lives at school that has a negative impact on trans children (Ryan et al., 2013). This culture of silence is reinforced through multiple means, from formal legislation against LGBT inclusion in school ${ }^{5}$ (Carlile, 2019), to teacher self-censure (Roberts et al., 2007), through to approaches that police offensive language without empowering teachers to provide alternative positive narratives (DePalma and Atkinson, 2009a).

A culture of silence is also promoted by cisnormativity, wherein any trans representation is perceived through a lens of hyper-visibility (DePalma and Atkinson, 2006). Trans (and LGB)

${ }^{5}$ Section 28 was a statute in place in the UK between 1988 and 2003, that banned the "promotion" of same-sex relationships in schools (Carlile, 2019). 
equality can be seen as controversial in a way that does not extend to other equalities (Atkinson and DePalma, 2008) with some commentators considering children "too young" to learn about their trans classmates (Bartholomaeus and Riggs, 2017a). The presence and increasing visibility of trans children in primary and nursery classrooms (Riggs and Bartholomaeus, 2018) forces primary school educators to face up to the silence surrounding trans lives (Payne and Smith, 2014). Unprepared schools can enter into "school panic," when a culture of silence comes up against the reality of trans children's lives (Smith and Payne, 2016; Bartholomaeus and Riggs, 2017a).

"When marginalised groups begin to challenge society's expectation that they will remain invisible and silent, they are faced with a choice between invisibility (where they have traditionally been assumed not to exist) and surplus visibility (where their mere presence seems excessive)." (DePalma and Atkinson, 2009b, 887).

Schools need to adopt a "usualising" approach to trans inclusion, where trans people are destigmatised to the point that their visibility is no longer of note (Iskander and Shabtay, 2018; Carlile, 2019). Trans people can be made part of everyday life through incorporation into different parts of the curriculum (Mitchell et al., 2014) moving trans lives in schools "from surplus visibility to ordinariness" (DePalma and Atkinson, 2009b, 884).

Curricula remain cis-dominated (Miller et al., 2018) with trans identities nearly invisible (Miller, 2016a). Many children do not see any representations of trans people at school (Mitchell et al., 2014; Peter et al., 2016). Erasure of trans visibility delegitimizes trans identities (Miller, 2016c), forming a systemic macroaggression where trans pupils need to continuously self-advocate and educate to be read as valid (Frohard-Dourlent, 2018). When schools do not affirm or represent trans identities, this impacts on trans children's self-image, belonging and sense of worth (Ullman, 2014; Miller, 2016a). Exclusion from the curriculum gives a message that trans identities are inferior (Miller, 2016c; Shelton, 2016). Marginalisation and exclusion at school and in wider society teaches trans pupils that there is no place for them in the school or the wider world (Ryan et al., 2013; Ullman, 2017).

Affirming trans-positive school environments are vitally important for trans pupils, improving mental health, wellbeing, self-esteem, school engagement, and sense of belonging (Olson, 2016; Bartholomaeus and Riggs, 2017a; Day et al., 2018). Children who are affirmed at home and at school have positive academic and emotional outcomes (Davy and Cordoba, 2019). Miller (2016a, 6) highlights the importance of schools being affirming with a "pedagogy of recognition" where trans pupils can see that they are valued, not merely tolerated. Trans representation can also have huge importance for gender questioning children, with access to the word trans, and knowledge of the existence of trans identities opening doors to self-discovery (Kennedy, 2018). Most pupils do not see any trans representation in schools (Bradlow et al., 2017), and the representation that does exists is mostly negative, framing trans people as "at risk" (Bittner et al., 2016). In these contexts trans pupils can gain confidence and self-esteem from any positive trans representation (Snapp et al., 2015).
An inclusive curriculum explicitly tackles the misconceptions that underpin transphobia (Meyer et al., 2016) and reinforces peer acceptance (Kosciw et al., 2012; Ryan et al., 2013), with increased peer support creating a more positive school climate for trans pupils (Kosciw et al., 2012; Jones et al., 2016). Trans representation in the classroom sends pupils a message that teachers support them, that they have a right to be safe in school (Kosciw et al., 2012; Peter et al., 2016), that they are not alone (Miller et al., 2018). A trans-affirmative curricula builds a more supportive, welcoming school climate (Peter et al., 2016; Martino and Cumming-Potvin, 2017), and improves well-being of trans pupils (Greytak et al., 2013; Kahn and Lindstrom, 2015).

Trans pupils who feel able to fully participate as an equal in school, being open, when they choose, about their identity and being able to discuss "transitude" (Ashley, 2018, 4) at school, had a greater sense of belonging (Greytak et al., 2009). Trans pupils having a sense of belonging at school correlates to pupil wellbeing, academic motivation and academic achievement (Kosciw et al., 2012; Ullman, 2015b).

Trans inclusion is needed in education about bodies and puberty (Jones et al., 2016), though with care not to limit inclusion to Relationships and Sex Education, which can be pathologising (Formby, 2015; Carlile, 2019). Trans positive representation in literature provides a "pedagogy of possibility" (Bittner et al., 2016, 2) that disrupts cisnormativity (CummingPotvin and Martino, 2018) showing trans people "as part of vibrant, supportive communities, living fulfilling, and productive lives" (Parsons, 2016, 11). Trans representation in history, showing historic fights for rights and visibility, helps validate and give hope to trans pupils, whilst also raising acceptance from cis peers (Snapp et al., 2015).

\section{Teacher Barriers to Action}

Trans pupils can experience bullying, transphobia, ignorance and hostility from teachers and school staff (Reed et al., 2010; Taylor and Peter, 2011; Kuvalanka et al., 2014; Formby, 2015; Bartholomaeus et al., 2017), causing significant harm (Robinson et al., 2014). Teachers can also contribute to a hostile climate through inaction when pupils are facing transphobic harassment (Greytak et al., 2009; McGuire et al., 2010; Robinson et al., 2014; Bowers et al., 2015; Ullman, 2015b, 2017; Kosciw and PizmonyLevy, 2016). Trans pupils who do not feel supported by their teachers are more than four times as likely to leave school if they encounter discrimination (Jones et al., 2016), with teacher failure to intervene seen as a violation of trust (Meyer and Stader, 2009).

Teachers have enormous power to "affirm or belittle the existence of youth in their classrooms" (Kearns et al., 2017, 12). Some teachers and school administrators are positive, wellinformed and affirmative, and even just one supportive and trusted teacher can make a profound impact on a trans pupil's experience of school (McGuire et al., 2010; Mulcahy et al., 2016; Bartholomaeus and Riggs, 2017a; Ullman, 2017; Palkki and Caldwell, 2018). In schools where teachers were protective and affirming (Meyer et al., 2016), consistently intervening to disrupt marginalising behaviour, pupils experienced lower rates of bullying (Greytak et al., 2013; Jones et al., 2016), had lower rates of school absenteeism (Ullman, 2015b; Jones et al., 2016), 
and higher rates of happiness and self-esteem (Kosciw et al., 2013; Ullman, 2015b). Perceived acceptance from teachers matters as much as protection (Ullman, 2014), with teacher positivity about gender diversity significantly correlated with pupil well-being (Ullman, 2015b, 2017). Trans pupils spoke of the importance of having at least one adult who could advocate for them, help them understand their rights, and help them navigate cisnormative institutional cultures and regimes (McGuire et al., 2010).

A key barrier to trans inclusion is teacher willingness, with some staff not believing it is their job to include or affirm trans youth (Meyer and Leonardi, 2018), or having "barriers to empathy" (Blair and Deckman, 2019, 2). Bowers et al. (2015) notes that school staff will be shaped by negative attitudes, misinformation or transphobia endemic in society. Teachers who were willing to refer to LGB identities in their classroom were less willing to include trans people (Formby, 2015), considering the topic taboo (Pullen Sansfaçon et al., 2015), too complex (Mitchell et al., 2014), or too difficult (Cumming-Potvin and Martino, 2018). However, once teachers tried trans and LGB inclusiveness, they were surprised to find children capable of engaging sensitively and thoughtfully (Carlile, 2019). School staff can be overwhelmed by inertia, aware of the need to support trans pupils, but holding on to pre-established prejudices of trans as an undesirable "deviation" (Frohard-Dourlent, 2018). Teachers and school administrators may wrongly assume the existence of transphobic institutional and legal regulations where discriminatory regulations do not exist (Frohard-Dourlent, 2016).

Teacher lack of knowledge remains a barrier (Pullen Sansfaçon et al., 2015; Bartholomaeus et al., 2017; Carlile, 2019). Ill-informed teachers can do harm, by relying on stereotypes that reinforce prejudice (Mitchell et al., 2014). Teachers may also experience fear and anxiety at the presence of trans children in their classroom (Payne and Smith, 2014; Smith and Payne, 2016; Blair and Deckman, 2019), the arrival of a trans child forcing teachers to become aware of (but not necessarily challenge) cisnormative assumptions and practices. Teachers lacked confidence in how to identify school practices that harm trans pupils, or in how to identify transphobic or cisnormative stereotypes, bias or prejudice in teaching materials (Bartholomaeus and Riggs, 2017a). Teachers preferred to focus on "the problem" of fitting trans pupils into a cisnormative school, prioritising individualised actions like name change, rather than considering wider trans-inclusive adaptations (Smith and Payne, 2016).

Teachers and school staff who have undertaken specific training on working with trans pupils, and those with trans friends or family, had more positive attitudes and greater confidence in working with trans pupils, and were more likely to advocate for their trans pupils (Bowers et al., 2015; Bartholomaeus et al., 2017). Staff who had knowingly taught at least one trans pupil had more positive attitudes on trans inclusion (Bowers et al., 2015; Bartholomaeus et al., 2017), building confidence with experience (Davy and Cordoba, 2019), However, a majority had not knowingly taught a trans pupil (Bowers et al., 2015). Mentorship arrangements between staff with prior experience and staff who are new to this were found helpful in raising confidence, though such support is rare, especially in primary schools (Slesaransky-Poe et al., 2013; Bartholomaeus and Riggs, 2017a; Davy and Cordoba, 2019).

Another barrier was teacher concern about wider community or parental opposition to support for trans pupils. Teachers were likely to assume parents as a whole would disapprove of LGBT inclusion (Depalma and Atkinson, 2010) and used this as justification for not acknowledging gender diversity in their teaching. Without school-set expectations, some teachers were likely to focus on the perceived preferences of transantagonistic parents, rather than centring the needs of trans children (Malins, 2016).

Teacher fear, underpinned by the impacts of anti-trans and anti-LGBT legislation, is a significant obstacle (Carlile, 2019), with teachers feeling they needed courage to deliver LGBT inclusive curricula (Atkinson and DePalma, 2008; Carlile, 2019). Teachers avoided the topic (DePalma and Atkinson, 2006; Cumming-Potvin and Martino, 2018), believing they needed explicit permission to talk about it (DePalma and Atkinson, 2009a). Teachers need a network of support to enable and encourage trans inclusivity (Malins, 2016). DePalma and Atkinson (2009a) emphasizes how teachers aiming for LGBT school equality may need extra cross-school support, as they can feel isolated and worry about being perceived as "subversive."

In locations like the UK, with a history of LGBT-exclusionary school legislation, proactive policy, and school-wide efforts are needed to ensure teachers gain confidence that trans inclusion is not controversial or unusual, but essential and routine (Mitchell et al., 2014). Similar efforts are needed when schools come under the pressure of conservative campaigns against trans-inclusion in education, campaigns that put pressure on schools in many countries to overlook their responsibility toward trans pupils (Jones et al., 2016; Bartholomaeus and Riggs, 2017a).

Reference to legal mandates and government or educational guidance is an important support for teachers and school administrators, making the connection to obligations to provide equality of opportunity safety, and physical and emotional wellbeing for all children (DePalma and Atkinson, 2009a; Mitchell et al., 2014; Carlile, 2019). Leadership, policies and guidelines from national or sub-national government are particularly helpful to ensuring school commitment (Bartholomaeus and Riggs, 2017b). Governments need to fulfil their responsibilities in providing clear legislation and guidance to uphold the rights of trans children in education (Riley, 2012). Unfortunately, governments are frequently slow on delivering this leadership (Riley, 2012; Neary and Cross, 2018), failing in their duty of care for trans children.

Martino and Cumming-Potvin (2018) reference the ways in which teacher action or inaction in support of trans pupils is influenced as much by media landscape as by formal policy, or the ways equality-related policies are framed and understood through media narratives. In contexts where national policy or media landscape is hostile to trans pupils, schools, and teachers having an ethical commitment to caring for their trans pupils becomes even more important (Miller et al., 2018). Leadership and support at school level are critical for teacher action (Malins, 2016). Class teachers look for assurance that they have their head 
teacher's backing (Mitchell et al., 2014). In many schools, head teachers (principals) are proactively working to ensure equality of opportunity for trans pupils (Meyer et al., 2016). Equality motivated school board members can play a critical role in ensuring teachers and school leadership have a clear mandate to support their trans pupils, ensuring teachers understand and tackle cisnormativity, providing a welcoming school (Meyer et al., 2016).

\section{Ambition and Allies}

The literature challenges the ambition we should have for transinclusivity in our schools, shifting from a focus on protection to school environments that affirm, validate, and welcome trans pupils as equals (Case and Meier, 2014; Snapp et al., 2015; Meyer and Leonardi, 2018; Sinclair-Palm and Gilbert, 2018); The literature emphasises the importance of teacher allies (Meyer et al., 2016) and the need to raise our imagination of what teachers and school administrators are able to do to support their trans pupils (Atkinson and DePalma, 2008; FrohardDourlent, 2016). Our ambition for teacher allies needs to move beyond protection of an individual pupil, to being willing to dismantle cisnormative structures, policies, and approaches that delegitimise and marginalise trans pupils (Case and Meier, 2014; Meyer et al., 2016; Peter et al., 2016; Marx et al., 2017; Meyer and Leonardi, 2018).

The systemic inequalities experienced by trans pupils represent a significant human rights issue (Greytak et al., 2009; Ullman, 2014; Martino and Cumming-Potvin, 2016), necessitating a shift from trans inclusion to trans emancipation in our schools (Mayo, 2007). Where there is a systemic injustice, as is the case for trans pupils in schools today, allies have a responsibility to act as advocates for social justice (Gonzalez and McNulty, 2010; Kearns et al., 2017). As well as mentoring and supporting empowerment of individual trans pupils to assert their rights, teacher allies can ensure there is clear communication across the school on trans equality, sponsor LGBT groups, educate school staff, and advocate for pupils' rights and well-being across the school and beyond the school gate (Gonzalez and McNulty, 2010; Case and Meier, 2014).

Teacher education and training needs to move beyond basic education on the existence of trans people and on transphobic bullying (Meyer and Stader, 2009; Parsons, 2016; Bartholomaeus and Riggs, 2017a). Trans pupils wanted teacher training to help ensure staff take action to tackle cisnormativity in educational systems and classrooms, improving equality of opportunity for trans pupils (McGuire et al., 2010; Frohard-Dourlent, 2018). Trans pupils often have a good understanding of the structural factors underpinning the challenges they face in school, and wanted school staff to acknowledge and be proactive in tackling these systemic barriers (McGuire et al., 2010). Training needs to help school staff understand the ways in which school cisnormativity marginalises trans pupils (McGuire et al., 2010), positioning trans pupils as lesser or other (Miller, 2016c; Marx et al., 2017). Trans pupils also wanted school educators to be more active in speaking up for trans rights in external processes and policy fora, helping them overcome areas of structural oppression that impede their access to justice and equality in education and beyond (McGuire et al., 2010).
Bartholomaeus and Riggs (2017a) highlight the many examples of cisgender teachers and school administrators who are already effectively advocating for, and standing up with, trans pupils in schools (Ryan et al., 2013; Martino and CummingPotvin, 2017). Feeling safe at school needs to be recognised as the bare minimum to expect for our trans children (Ullman, 2015a) with educators needing to go further and ensure schools are inclusive and affirming (Bartholomaeus and Riggs, 2017a) places where trans pupils belong, where they are loved, where they succeed and thrive (McGuire et al., 2010; Miller et al., 2018). Miller (2016b) aspires to a future where trans pupils are commonplace and normalised, where gender diversity does not lead to macroaggressions or marginalization, where there is trans representation across all school materials and curricula, where schools support and embrace trans pupils of all ages.

\section{Child Voice and Child Rights}

A child-rights informed approach centres trans children's right to an educational experience that is safe, inclusive and affirming, a right to "gender legibility" (Miller, 2016c, 34), in schools where they can have an equitable experience to their cis classmates. Trans children have a right to privacy, to gender marker change, and a right to choose if, and how, and when, to disclose their gender modality (that they are trans) (McGuire et al., 2010). Trans children also have a right to be visible in schools, open about their transitude to their classmates and school. Riggs and Bartholomaeus (2018) provide an example of a parent feeling their child and family had been pushed toward not disclosing their transitude, to simplify the situation for the school and other parents, rather than centring the needs and rights of the child.

There remain incidences where trans children's existing legal rights are not respected and where schools fail in their legal duty toward trans children (Taylor and Peter, 2011; Ingrey, 2018). In countries where trans children have legal protection, schools need to ensure administrators, teachers and pupils are aware of these rights, and mechanisms need to be in place to hold schools accountable when these are not fulfilled (Schindel, 2008). Schools also have a responsibility to advocate for trans children's needs and rights, including through educating unsupportive or unenlightened parents (Grossman et al., 2009). Trans children and supportive parents need to know their rights in order to claim them (Davy and Cordoba, 2019), and in order to challenge where there is ongoing inequality and injustice (Schindel, 2008). Meyer and Keenan (2018) outline the limitations of legally mandated protection of trans children, arguing that beyond an individual trans child's rights, there must be a focus on a school's responsibilities, ensuring there is institutional accountability for systemic change.

LGBTQ clubs (GSA in North America) can provide trans children with peer support in an affirming and safe space, and an escape from ignorance and cisnormativity (McGuire et al., 2010; Taylor and Peter, 2011; Kosciw et al., 2012, 2016; Marx and Kettrey, 2016). Trans youth with access to a GSA report more welcoming school climates, lower rates of victimization, greater feelings of school connectedness, and less school absenteeism (Greytak et al., 2013). GSA members report a greater sense of empowerment (Poteat et al., 2016), can come together to jointly challenge systemic injustice and advocate for changes at school 
(Greytak et al., 2009; Gonzalez and McNulty, 2010), increasingly prioritising trans related advocacy (Poteat et al., 2018). Trans pupils who feel empowered and know their rights, who framed the discrimination they endure as related to societal and systemic prejudice, were more likely to respond with activism, and more likely to feel optimistic about being able to contribute to social change (Jones and Hillier, 2013; Jones et al., 2016). Luecke (2018) discusses components of a "Gender Facilitative School," with an emphasis on empowering all children to be advocates and supporters of their gender expansive peers.

Many studies note the resilience of trans pupils, their agency to resist injustices and advocate for themselves and their peers (McBride, 2020). Wernick et al. (2014) emphasise that marginalised youth need to identify and drive their own solutions, including through educating peers to join them in collective action. Kjaran and Jóhannesson (2013) highlight the importance of an emancipatory approach that prioritises listening to trans pupils' stories, including their experiences of encountering and resisting cisnormativity and structural violence. However, minority youth cannot be left to single-handedly challenge ingrained and dominant systems of cisnormativity, and the institutional and systemic discrimination that affects their lives (McBride, 2020).

\section{REVIEW OF UK TRANS-INCLUSION SCHOOL GUIDANCE DOCUMENTS}

This section summarises an analysis of a sample of recent UK school guidance documents, examining the degree to which themes, findings and recommendations from global literature are represented. It reviews the eight themes from the global literature, finding varied representation of these themes in UK school guidance documents.

\section{Varied Commitment to Depathologisation and Trans-positivity}

Many of the guidance documents contained instances of pathologisation of trans children. Four types of pathologisation were noted: delegitimisation, problematisation, medicalization, and deficit framing. Guidelines on trans inclusion need a stronger commitment to avoiding pathologisation of trans children within their text, alongside working toward depathologisation of trans identities across our schools.

Across the guides there are a number of examples where language and phrasing others and pathologises trans children. There are examples of misgendering with Education Authority Northern Ireland $(2019,11)$ describing trans feminine children as "birth assigned males." Education Authority Northern Ireland (2019) delegitimises younger trans children, referencing an older research study on desistance ${ }^{6}$, that has been heavily criticised by modern research literature as flawed and pathologising (Ehrensaft et al., 2018; Newhook et al., 2018b; Turban and Keuroghlian, 2018). A number of the guides completely avoid the term "trans children" in a way that marginalises and delegitimises

${ }^{6}$ Itself a problematic and pathologising concept (Newhook et al., 2018a). younger trans children, for example talking of children who "want to live in a different gender" LGBT Youth Scotland (2017, 10), using the phrase "trans young people" throughout (Equaliteach, 2020) or "children who are questioning their gender identity" (Stonewall, 2018, 12). Each of these phrases has a place, as long as it is alongside and not instead of acknowledgment of the existence of trans children. Other guides including Leeds City Council (2018), Brighton and Hove City Council (2019) and the Trans Inclusion Toolkit (2019), confidently use the term "trans children," an important step in combatting erasure, stigmatisation and pathologisation. Brighton and Hove City Council (2019) normalises the term trans children across its guide, stating that many trans people are aware of their identities at (or before) primary school. The Trans Inclusion Toolkit (2019) outlines the importance of affirming trans children.

There are a number of examples where guides problematize trans children. Education Authority Northern Ireland (2019, 7) has a section "We do not know exactly why people are transgender," without asking why people are cisgender, an inherently othering frame. Brighton and Hove City Council $(2019,7)$ is clear on the need to avoid problematisation of trans pupils: "Avoid seeing the trans or gender-questioning child or young person as a problem and instead see an opportunity to enrich the school community." There are a number of areas in which trans children are medicalised and pathologised, with Education Authority Northern Ireland (2019, 8,37) making reference to a "clinical condition," and the suggestion that "medical advice may be sought" when responding to younger children. EANI adopts a pathologising and medicalising framing to social transition, whereas the Trans Inclusion Toolkit (2019) has a depathologised and demedicalised section on social transition, making clear it is not linked to medical services.

Many of the guides frame trans children as inherently at risk and in need of protection, devoting significant space to statistics on bullying, abuse, school drop-out and suicidality amongst trans pupils. Some guides make clear that these negative outcomes are not intrinsic to being trans-Brighton and Hove City Council $(2019,11)$ states: "many of these problems are not caused by being trans but by society's attitude toward people who are trans." The Trans Inclusion Toolkit $(2019,12)$ makes clear that risk factors for mental health are "a result of unsupportive social contexts and responses that they encounter due to prejudice and lack of understanding." LGBT Youth Scotland (2017) emphasises the pathologisation that underlies much parental rejection of trans children, arguing that schools have an important role to play in depathologising trans identities.

\section{Strong on Transphobic Bullying-Varied on Protection From Discrimination}

Basic guidance on avoiding illegal discrimination is prioritised in many of the school guidance documents, outlining the school's obligations to allow name changes or access to appropriately gendered bathrooms, with many making a connection to relevant legislation including the 2010 Equality Act: "so trans girls because they are girls, can use the girls' toilets" (Trans Inclusion Toolkit, 2019, 25). The guides vary in how clearly they 
prioritise protecting trans pupils from discrimination, especially in situations where others want to exclude or segregate them. LGBT Youth Scotland $(2017,18)$ prioritises protecting trans children from discrimination: "If a learner feels uncomfortable sharing facilities with a transgender young person, they can be allowed to use a private facility such as an accessible toilet, or to get changed after the trans young person is done. A transgender young person should not be forced to use alternative facilities simply to make other young people feel more comfortable." Conversely, Education Authority Northern Ireland (2019, 34) does not fully support trans pupils, suggesting staff need to consider "the needs of other pupils." Education Authority Northern Ireland (2019) also suggests that a trans pupil's own safety can be a reason to deny them access to their preferred facilities, penalising a pupil for their school's failure to keep them safe. This can be contrasted with guidance from LGBT Youth Scotland $(2017,21)$ which is clear that "risk assessments should not be used to exclude a transgender young person."

Many of the guides focus heavily on bullying - in fact several of the sampled guides are specifically on HBT (Homophobic, biphobic, transphobic) bullying. There has been a significant UK investment in work to tackle HBT bullying, including pilot initiatives and an evaluation of the effectiveness of different approaches to HBT bullying (Case and Meier, 2014; Mitchell et al., 2016). There needs to be awareness that HBT guides may not go beyond this topic, into other areas which are critical for trans inclusion and trans equality.

All of the guides discuss transphobic bullying, particularly in terms of intentional transphobia and a focus on a single, peer, bully to victim dynamic. Several guides commit to policing abusive language, though do not prioritise action to address underlying views or education to replace transphobic frames with trans-positive ones. The Trans Inclusion Toolkit (2019) meanwhile emphasizes the need to explore and explain when pupils ask inappropriate questions or use transphobic language. Many of the guides associate transphobia with extreme overtly abusive language. The Trans Inclusion Toolkit (2019) on the other hand centres the voices of trans children, who share their experiences of subtler harassment, providing an annex of trans children sharing examples of inappropriate and invalidating questions.

\section{Minimal Consideration of Cisnormativity}

The school guidance documents have minimal consideration of cisnormativity, or the ways in which persistent cisnormativity manifests as continuous microaggressions, making trans children stressed, unwelcome and emotionally unsafe at school.

A wide number of the guides do not even mention the term cisnormativity (Brighton and Hove City Council, 2019; Trans Inclusion Toolkit, 2019; Stonewall, 2020), and whilst others (Equaliteach, 2020) provide a definition, they do not devote space to unpacking how cisnormativity affects trans children's well-being at school.

Overall, the guides give very limited consideration to the systemic changes which are needed to make trans children welcome in our schools. Most of the guidance documents consider the support needed at the point of a pupil's social transition, but appear unaware of ongoing adaptations that trans pupils may need to tackle institutional cisnormativity (Stonewall, 2020). Brighton and Hove City Council (2019) mentions that trans inclusion requires a whole school and community to shift their thinking and understanding, but does not consider implications in terms of shifts in behaviour or systems. Leeds City Council (2018) mentions the need to build trans youth resilience, without considering school responsibilities to ensure trans youth are not living under stress and discrimination.

Many of the guides, particularly for primary schools (Leeds City Council, 2018), do talk about systemic change when discussing the need to challenge gender stereotypes, including the reduction of gendered restrictions and practices. Although this work is useful to all pupils trans and cis, there needs to be recognition that work on gender stereotypes alone is insufficient to overcome the structural cisnormativity that can make schools a hostile environment for trans children.

\section{Reactive Rather Than Proactive Approach to Trans Inclusion}

Many guides place an important emphasis on listening to each individual child, hearing and understanding their individual needs and preferences. However, most of the guides do not mention the burden an individualised and reactive approach places on the shoulders of trans children. LGBT Youth Scotland (2017) refers to the extent trans pupils have to self-advocate throughout their time in education and the Trans Inclusion Toolkit includes a quote from a trans pupil illustrating the burden when they are forced to educate an unprepared school.

Few of the guides explicitly talk about trans children's rights at school. Stonewall (2020) gives a transition check-list that does not mention explaining to a trans pupil their rights. Education Authority Northern Ireland (2019) particularly fails to centre child rights in suggesting a school's commitment to trans inclusive adaptations will depend on a school's ethos and financial resources. Education Authority Northern Ireland (2019, 19) also fails to centre a child's right to an affirming name or pronoun, framing decisions on pronoun change as a "significant change" to be decided by the school rather than the individual pupil. LGBT Youth Scotland $(2017,28)$ puts each young trans person at the centre "Ask the young person how they would like you and the school to support them." Without first explaining to a trans child their rights, they may not be aware of how many accommodations they can ask for, especially given the power dynamics at play between cis adults and trans children.

Many of the guides suggest trans inclusion starts at the point of a school knowingly having a pupil ask about transition. The Trans inclusion toolkit emphasises that schools need to provide a trans inclusive environment regardless of whether they knowingly have trans pupils, considering children who have not yet transitioned, as well as pupils who have already transitioned but not disclosed their gender modality. Many of the guides expect trans pupils to make individualised requests before accessing appropriate facilities and expect trans pupils to submit to a review process before gaining permission (National Education Union, 2018; Brighton and Hove City Council, 2019; Trans Inclusion Toolkit, 
2019). The guides do not outline the importance of ensuring trans pupils know their rights, or the importance of proactively communicating trans inclusive policies to the school community. Brighton and Hove City Council $(2019,7)$ is clear that trans pupils should not be made to feel like they are privileged for getting basic accommodations "No trans pupil or student should be made to feel that they are the ones who are causing problems or that they owe anything to their school in return for changes made to support them."

Many of the guides talk about individualised discussions for school and curricular adaptation to an individual pupil-for example Brighton and Hove City Council (2019) talks positively about working with a parent to adapt a lesson on reproduction to ensure it was trans inclusive. There is no consideration of how to ensure adaptations are embedded and sustained, no consideration of the pressure this places on individual pupils or families at a time when pupils and families may be unclear on their rights, and no consideration of the inefficiencies of each trans child negotiating individualised solutions rather than learning from existing good practices. The Trans Inclusion Toolkit $(2019,6)$ makes reference to the burden shouldered by trans pupils tasked with negotiating their own trans-inclusive adaptation-one child expressed hope that the trans inclusion toolkit "will take the responsibility for educating people off me."

\section{Moderate Emphasis on Inclusion and Representation}

Stonewall (2020) and LGBT Youth Scotland (2017) are strong on arguing that an absence of trans representation in our schools sends a negative message, whereas a trans inclusive curriculum embeds positive messages about trans people into regular teaching, normalising trans people as a usual and valued part of our communities. LGBT Youth Scotland $(2017,32)$ makes clear the case for representation: "Transgender young people typically wait 4 years before talking to someone about their gender identity. During that time, they may not see or hear anything about transgender people, identities or topics at school." They also include a quote from a trans pupil "Definitely there needs to be more transgender inclusion in education-we didn't even get a single mention of being trans at my school" (LGBT Youth Scotland, 2017, 32).

The suggested examples of trans inclusion can be limited, with some LGBT guidance documents failing to mention trans examples (Chief Rabbi Ephraim Mirvis, 2018). Stonewall (2019) includes a number of examples, but further consideration could be made on how to ensure teachers conduct discussions in a way that affirms trans pupils. Brighton and Hove City Council (2019) commits to inclusive SRE including in teaching on body parts and puberty-ensuring this is validating both for trans pupils and in the impression conveyed to their cis peers.

There is a suggestion across numerous guides that early years and primary work on gender stereotypes equals support for trans students. All pupils will benefit from work on gender stereotypes, but younger trans pupils, who may or may not be gender nonconforming (Olson and Enright, 2018), need additional areas of action. The Trans Inclusion Toolkit $(2019,17)$ is very clear on the point at which trans inclusion is appropriate: "The appropriate age to discuss the existence of trans and LGB people is the same time it is appropriate to talk about the existence of heterosexual relationships and the existence of boys and girls." This can be contrasted to Education Authority Northern Ireland (2019) which talks about age appropriateness, controversy, and recommends inclusion at secondary school-age $11+$.

LGBT Youth Scotland (2019) recommends talking about trans professionals in light of their professional achievements and commenting in passing at the end of a lesson that they are trans, normalising trans people and demonstrating inclusion in action.

\section{Varied Attention to Teacher Barriers}

Trans Inclusion Toolkit (2019) mentions that school staff can deliberately misgender trans pupils, and are clear that this is a serious concern, an act of harmful behaviour toward a child; as well as highlighting how teachers can inadvertently cause harm through inappropriate questions. Trans Inclusion Toolkit (2019) explains that poor relationships with teachers can be a risk factor for trans children experiencing poor mental health. LGBT Youth Scotland (2019) provides an example scenario and recommended actions if a teacher is deliberately using the wrong pronoun.

Trans Inclusion Toolkit $(2019,6)$ also highlights a trans child explaining where teachers can make a difference "If one person in school asks the right questions, uses the right name and the right pronouns it can make such a huge difference to a young person. It can help them carry on and live another day." LGBT Youth Scotland $(2019,9)$ "expects all teachers to be positive role models to all young people in showing respect to transgender young people."

Trans inclusion toolkit ends with an annex of trans child quotes which really highlight the impact when schools fail in their duty of care to trans children, including the ways in which impacts on mental health and self-esteem are undervalued: " $I$ don't drink all day at school so that I don't have to go to the toilet which means I'm always dehydrated and I get headaches all the time and UTIs. Teachers need to know this because it's easy to ignore all the consequences when it's just our mental health but when it's physical they suddenly listen."

Trans Inclusion Toolkit (2019) mentions importance of training to ensure "all teachers feel confident to support trans children." Brighton and Hove City Council (2019) provides scripts for potential difficult questions from wider parents, but does not examine the prejudices, fears or misconceptions that may impede teachers from being supportive.

Very few of the guides explicitly identify and address barriers that may impede teachers from effectively including and affirming trans pupils. LGBT Youth Scotland (2019) simply states that if staff are reluctant they should be reminded of their duty of care to all learners. The Trans Inclusion Toolkit $(2019,6)$ alludes to teacher related challenges in a quote from a trans child "This toolkit will help people who are scared and sadly, all too often, unwilling to do the right thing."

Equaliteach (2020) dedicates space to identifying and addressing barriers to teachers creating affirming schools, including ensuring support for younger trans children. Equaliteach (2020) considers mandate, leadership, governance, staff support, working groups and efforts to institutionalise and sustain change. 


\section{Low Expectations for Allies and Outcomes}

The documents presented a fairly low bar on teacher and staff expectations, with ambitions framed primarily in terms of being a supportive listener and intervening in transphobic bullying. There was little discussion of practical steps teacher allies can take to disrupt cisnormativity, to reduce the stress carried by trans pupils navigating a cisnormative world.

Equaliteach (2020) framed teacher allies as people who would challenge a HBT incident, who are aware of their legal duties and who understand basic trans related terminology. The level of ambition in LGBT Youth Scotland (2017) in terms of standing up for trans children in primary schools is also very low, prioritising avoidance of gender stereotypes. Stonewall (2020) is a document on next steps in LGBT inclusion, but it is still very basic in its ambition on trans affirmative education. It largely focuses on gender stereotypes, on the fact trans people exist and on supporting pupils who transition to access their legal minimum rights, without commitment to more systemic change.

Brighton and Hove City Council $(2019,6)$ sets its ambition higher on "developing whole school policy and practice that will allow trans children and young people to achieve at school." However, the included parent case studies imply satisfaction at basic accommodations of trans children in schools, giving an impression that a school not discriminating against trans pupils is a success. One case study written in a partially positive way included examples of significant school failurea child never going to the toilet at school-suggesting low parental expectations.

Trans Inclusion Toolkit $(2019,13)$ calls for higher ambition, emphasising that poor outcomes are not intrinsic to being trans and that schools have a crucial responsibility: "It is vital that schools and education settings don't present negative outcomes as expected futures to children and families. Staff should work to mitigate risk, safeguard children and families and support the development of positive outcomes."

\section{Varied Commitment to Child Voice and Child Rights}

The school guidance documents vary in how effectively they centre trans children's rights, and in how much they listen to trans children's voices, experience, concerns, and priorities.

The guides vary in their commitment to child rights. Several guides reference the UN Convention on the Rights of the Child (Trans Inclusion Toolkit, 2019), outlining that trans pupils "should be involved in all decisions affecting them, understand any action which is taken and why; and be at the centre of any decision making" (LGBT Youth Scotland, 2017, 8). Several guides reference trans children's right to privacy (Brighton and Hove City Council, 2019; Trans Inclusion Toolkit, 2019), and their right to an education free from discrimination and prejudice (LGBT Youth Scotland, 2017). Brighton and Hove City Council (2019) states categorically that trans children have the right to access correct facilities, though in one section appears to qualify this right: "As far as possible, trans pupils and students should be able to sleep in dorms appropriate to their gender identity."
The degree to which guides centre child rights is central to their approach to social transition. Education Authority Northern Ireland $(2019,19)$ describes their approach as informed by a child rights based approach, yet balances a trans child's wish to transition with "the need to protect the child from the negative reaction of others." Decision making around transition is thus put in the hands of adult staff-likely to be cis. A genuinely child-centred approach is found in LGBT Youth Scotland (2017), which is clear that decision making on transition timelines is in the hands of the trans pupil, stating that "delaying a transgender young person's wish to transition could negatively affect their mental health." Brighton and Hove City Council (2019) and the Trans Inclusion Toolkit (2019) both emphasise that a school's duty when working with parents or guardians is to represent the interests of the child, to ensure the child's voice is heard and to be their advocate.

The guides vary in how much they centre trans children's voices, with the Trans Inclusion Toolkit (2019) strong on including trans children's quotes throughout. Brighton and Hove City Council (2019) is a third edition that has been developed and informed by "the voice of trans children, young people, adults and their parents and carers." In terms of giving platforms for trans children to share their experiences, Stonewall (2020) includes an example of a secondary school where confident trans pupils are invited to give assemblies to all students on their experiences and how others can help. However, the example from a primary school is just on gender stereotypes, leading to a question on whether there is prioritisation on hearing the voice of younger trans pupils.

Many of the guides explicitly prioritise asking pupils prior to a social transition their views on their needs and preferences in terms of their individual transition. There is not a similar commitment to asking trans pupils who have already transitioned to share their views on systemic changes that would make the school better for themselves and current and future trans pupils. Education Authority Northern Ireland (2019) however, did include examples of gaining the views of trans pupils through meetings with the deputy head and through a confidential survey.

The Trans Inclusion Toolkit (2019) has a trans inclusion checklist for a school to self-complete, likely from the perspective of cis teachers or school administrators who do not directly experience the challenges that trans pupils face in a cisnormative school. It would be more ambitious if schools sought a trans pupil perspective on whether the school is matching up to its ambitions on trans inclusion.

\section{CONCLUSION}

In terms of trans-positivity, many, but not all, of the recent school guidance documents are prioritising affirmative language when writing about trans children. Language plays an important role in how school staff understand and engage with trans children and adolescents, and efforts to avoid pathologisation and ensure trans-positivity are critical. The majority of documents included emphasis on trans visibility and representation, though only few of them outline the reasons for the importance of visibility. Some 
schools provide visibility targeted at trans pupils, so they can see a positive future for themselves, while failing to note the equal importance of trans visibility for cis pupils, to increase the legitimacy of trans lives, and to reduce the burden on trans pupils to educate and explain themselves to their peers. For trans pupils in our nursery, primary and secondary schools, questioning and ignorance exert a daily toll, a burden that is unreasonable for young shoulders to carry. Visibility and representation have multiple important benefits, letting trans pupils know that they are not alone, giving reassurance that the school supports and will stand up for trans pupils, providing a sense of school belonging to trans pupils, and legitimising trans pupils in front of their cis peers.

The literature identifies some shifts needed in trans inclusive education. At the heart this represents a shift in expectations and ambition for trans pupils, from aspiring for resilience and protection from violence and abuse, to aspiring for self-confident, secure pupils who are validated and represented both in daily school life and across the curriculum, children with equality of opportunity to their cis peers, pupils who can excel and thrive at school. In one interview a school head teacher approvingly remarked that trans pupils weren't looking for basic safety or basic access to facilities, they "wanted everything to change" (Sadowski and Jennings, 2016, 83). Given the growing numbers of trans children confident to come out in our schools (Telfer et al., 2015), schools need to give greater consideration of how they can ensure the well-being of these children, helping them grow up as happy, healthy and supported members of our schools (Neary, 2019).

One critical shift is from a narrow definition of school safety to a focus on emotional safety. Violence and transphobic abuse remain serious concerns for too many trans pupils. Yet, even in contexts where schools have a commitment to protection from transphobic bullying, trans pupils experience cisnormative microaggressions that impact on their well-being. Commitment to tackling intentional transphobic bullying is very important, but it is only a first step toward a positive school climate for trans pupils, not an end goal. Underpinning this shift is commitment to understanding the ways in which trans pupils experience and are negatively impacted by systemic cisnormativity, the additional burden this places on trans pupils' shoulders and the cumulative toll it takes. Cisnormativity contributes to minority stress (Meyer, 2003), negatively impacting on well-being and mental health.

A second key shift is in acknowledging the barriers to transemancipatory education. There are pressures and disincentives to trans-inclusive practice that need to be recognised and strategically addressed. These barriers include the culture of silence surrounding LGBT and especially trans lives in schools, with educators in the UK still constrained by the after-effects of discriminatory legislation such as section 28. Teacher attitudes and confidence combine to create a second barrier that needs to be addressed, with a complex interplay between teachers who are prejudiced, teachers who feel creating a trans inclusive atmosphere is political (in a way that cisnormativity is not considered political), teachers who deprioritize the needs of trans children in view of assumed parental conservatism, and the teachers who feel under-trained or under-supported to act. Clear leadership is essential, and in the absence of strong trans-inclusive leadership at national level this leadership and commitment needs to be shown by governors, head teachers and individual members of staff.

A third shift that is needed is from individualised accommodation to proactive adaptation. Many school staff undergoing trans-inclusivity training perceive it as not directly relevant to their practice as they do not knowingly have a trans pupil in their class. However, given prevalence estimates, most teachers will have taught a trans pupil, they may just not have been aware. At present, trans-inclusive adaptations are too often prompted by a specific pupil, a "sacrificial lamb" who sends a school into "panic," and for whom individualised adaptations are made, adaptations that may not be sustained or transferred to wider classes. The pressure that this individualised approach puts on pioneer children and families is immense and unreasonable. The current emphasis on following an individual child's needs and preferences is absolutely critical, but this should not be a replacement for schools making pre-emptive and sustained changes to benefit current and future trans pupils.

The fourth shift that is required is from accommodation to a rights and responsibilities based approach. Current emphasis in schools is on asking trans students what they want and seeing what adaptations can be accommodated, a "negotiation" approach. Trans pupils and families may not be aware of their rights, or may be uncomfortable claiming their rights. A child rights based approach emphasizes the entitlements that trans pupils have, and is clear that these rights are neither negotiable or limitable. There also needs to be a shift from individual rights to institutional responsibilities, ensuring schools are fulfilling their duty of care to trans pupils.

Lastly, we must raise our ambition of what it means to be an effective ally to trans pupils. The bar needs to be raised from a basic level of respect-using correct pronouns, not discriminating against trans pupils, intervening in cases of abuse-to shifting the systemic injustices that harm trans pupils. Integral to this is an understanding of cisnormativity within education systems and cultures, and the ways in which cisnormativity privileges cisgender individuals and makes life harder for trans pupils. Trans pupils shoulder a triple burden of persistent often unintentional delegitimisation; having to, often single-handedly, educate about gender diversity and cisnormativity; and having to self-advocate for their right to a trans-inclusive school. In the absence of effective and informed allies, trans pupils face this challenge alone. This burden is even harder to bear for the many trans pupils facing additional stresses, including those who have unsupportive or abusive families, those facing harassment and hate inside and outside of school, and those with wider intersecting axes of marginalisation including disabled trans children, neurodiverse trans children and trans children of colour.

\section{LIMITATIONS AND AREAS FOR FURTHER STUDY}

This study has relied on secondary data, including analysis of existing literature and school guidance documents. The literature review provides limited insight on intersectional experiences, 
for example on the experiences of disabled, neurodiverse or black trans children. The literature has limited consideration of non-binary or gender fluid children, and limited data on trans children who are not supported at home. Finally the literature has limited first-hand accounts from trans children of their experiences, especially from younger pre-adolescent trans children. The conclusions and recommendations in this study can be strengthened through interviews and analysis with key informants including teachers, youth workers and parents of trans children. The research can be further improved by targeted interviews with trans children, gaining their insights into the findings and recommendations outlined above,

\section{REFERENCES}

Airton, L., and Koecher, A. (2019). How to hit a moving target: 35 years of gender and sexual diversity in teacher education. Teach. Teach. Educ. 80, 190-204. doi: 10.1016/j.tate.2018.11.004

Alegría, C. A. (2018). Supporting families of transgender children/youth: Parents speak on their experiences, identity, and views. Int. J. Transgenderism 19, 132-143. doi: 10.1080/15532739.2018.1450798

Ansara, Y. G., and Hegarty, P. (2012). Cisgenderism in psychology: pathologising and misgendering children from 1999 to 2008. Psychol. Sex 3, 137-160. doi: 10.1080/19419899.2011.576696

Ashley, F. (2018). Don't be so hateful: the insufficiency of anti-discrimination and hate crime laws in improving trans well-being. Univ. Tor. Law J. 68, 1-36. doi: 10.3138/utlj.2017-0057

Ashley, F. (2019a). Gender (De)transitioning before puberty? A response to steensma and Cohen-Kettenis (2011). Arch. Sex Behav. 48, 679-680. doi: 10.1007/s10508-018-1328-y

Ashley, F. (2019b). Homophobia, conversion therapy, and care models for trans youth: defending the gender-affirmative approach. J. LGBT Youth 1-23. doi: $10.1080 / 19361653.2019 .1665610$

Ashley, F. (2019c). Thinking an ethics of gender exploration: Against delaying transition for transgender and gender creative youth. Clin. Child Psychol. Psychiatry 24, 223-236. doi: 10.1177/1359104519836462

Ashley, F. (2019d). 'Trans' Is My Gender Modality: A Modest Terminological Proposal. Available online at: https://www. florenceashley.com/uploads/1/2/4/4/124439164/florence_ashley_ trans_is_my_gender_modality.pdf?fbclid=IwAR3nA6OzEE7TuWxMKZxz46 6mxsLDooa9KDXzsfBFCw29fYrqdhApxHIFB_w (accessed May 25, 2020).

Atkinson, E., and DePalma, R. (2008). Dangerous spaces: constructing and contesting sexual identities in an online discussion forum. Gend. Educ. 20, 183-194. doi: 10.1080/09540250701797192

Baldwin, D. R. (2015). Parents' Experiences as They Interact with Their Transgender Children's Schools. Available online at: https://ibrary.ndsu.edu/ir/handle/ 10365/27682 (accessed May 16, 2020).

Bartholomaeus, C., and Riggs, D. W. (2017a). Transgender People and Education. New York, NY: Palgrave Macmillan.

Bartholomaeus, C., and Riggs, D. W. (2017b). Whole-of-school approaches to supporting transgender students, staff, and parents. Int. J. Transgenderism 18, 361-366. doi: 10.1080/15532739.2017.1355648

Bartholomaeus, C., Riggs, D. W., and Andrew, Y. (2017). The capacity of South Australian primary school teachers and pre-service teachers to work with trans and gender diverse students. Teach. Teach. Educ. 65, 127-135. doi: 10.1016/j.tate.2017.03.006

Bauer, G. R., Hammond, R., Travers, R., Kaay, M., Hohenadel, K. M., and Boyce, M. (2009). "I don't think this is theoretical; this is our lives": how erasure impacts health care for transgender people. J. Assoc. Nurses AIDS Care 20, 348-361. doi: 10.1016/j.jana.2009.07.004

Bittner, R., Ingrey, J., and Stamper, C. (2016). Queer and trans-themed books for young readers: a critical review. Discourse Stud. Cult. Polit. Educ. 37, 1-17. doi: 10.1080/01596306.2016.1195106

Blair, E. E., and Deckman, S. L. (2019). "We cannot imagine": US preservice teachers' Othering of trans and gender creative student experiences. Teach. Teach. Educ. 86:102915. doi: 10.1016/j.tate.2019.102915 additional steps that will be part of ongoing $\mathrm{PhD}$ research by the author.

\section{AUTHOR CONTRIBUTIONS}

The author confirms being the sole contributor of this work and has approved it for publication.

\section{ACKNOWLEDGMENTS}

With thanks to Anna Carlile; Sheryl Clark; Josella Hervey; Jo Hirst; Sam Martin, Lisa Vine, and Anna Chivers.

Bowers, S., Lewandowski, J., Savage, T. A., and Woitaszewski, S. A. (2015). School psychologists' attitudes toward transgender students. J. LGBT Youth 12, 1-18. doi: 10.1080/19361653.2014.930370

Bradlow, J., Bartram, F., Guasp, A., and Jadva, V. (2017). The School Report 2017. London: Stonewall. Available online at: https://www.stonewall.org.uk/system/ files/the_school_report_2017.pdf (accessed May 26, 2020).

Brighton and Hove City Council (2019). Trans Inclusion Schools Toolkit. Brighton: Brighton and Hove City Council. Available online at: https://uploadsssl.webflow.com/5888a640d61795123f8192db/5c0ff2e6f554ac6a3f017600_ Trans_Inclusion_Schools_Toolkit_Version_3.3_Jan2019.pdf (accessed May 24, 2020).

Brill, S., and Pepper, R. (2008). The Transgender Child: A Handbook for Families and Profes-sionals. San Francisco, CA: Cleis Inc.

Bryant, K. (2006). Making gender identity disorder of childhood: Historical lessons for contemporary debates. Sex. Res. Soc. Policy 3, 23-39. doi: $10.1525 /$ srsp.2006.3.3.23

Bryant, K. E. (2007). The Politics of Pathology and the Making of Gender Identity Disorder - ProQuest. Available online at: https://search.proquest.com/ openview/06f10cc9e9b63c310197fbe32694883e/1?pq-origsite $=$ gscholar\&cbl= 18750\&diss $=y$ (accessed October 3, 2019).

Capous-Desyllas, M., and Barron, C. (2017). Identifying and navigating social and institutional challenges of transgender children and families. Child Adolesc. Soc. Work J. 34, 527-542. doi: 10.1007/s10560-017-0491-7

Carlile, A. (2019). Teacher experiences of LGBTQ- inclusive education in primary schools serving faith communities in England, UK. Pedagogy Cult. Soc. 1-20. doi: 10.1080/14681366.2019.1681496

Case, K. A., and Meier, S. C. (2014). Developing allies to transgender and gendernonconforming youth: training for counselors and educators. J. LGBT Youth 11, 62-82. doi: 10.1080/19361653.2014.840764

CASW ACTS (2015). Joint Statement on the Affirmation of Gender Diverse Children and Youth. Canadian Association for Social Work Education (CASWEACFTS) and the Canadian Association of Social Workers (CASW). Available online at: https://www.casw-acts.ca/fr/node/1987 (accessed October 3, 2019).

Chief Rabbi Ephraim Mirvis (2018). The Wellbeing of LGBT Pupils A Guide for Orthodox Jewish Schools. Available online at: https://chiefrabbi.org/wpcontent/uploads/2018/09/The-Wellbeing-of-LGBT-Pupils- A-Guide-forOrthodox-Jewish-Schools.pdf (accessed May 24, 2020).

Church of England Education Office (2019). Valuing All God's Children: Guidance for Church of England Schools on Challenging Homophobic, Biphobic and Transphobic Bullying. The Church of England Education Office. Available online at: https://www.churchofengland.org/sites/default/files/2019-07/ Valuing\%20All\%20God\%27s\%20Children\%20July\%202019_0.pdf （accessed May 24, 2020).

Cumming-Potvin, W. M., and Martino, W. (2018). Countering heteronormativity and cisnormativity in Australian schools: examining English teachers' reflections on gender and sexual diversity in the classroom. Teach. Teach. Educ. 74, 35-48. doi: 10.1016/j.tate.2018.04.008

Davy, Z., and Cordoba, S. (2019). School cultures and trans and genderdiverse children: parents' perspectives. J. GLBT Fam. Stud. 16, 1-19. doi: 10.1080/1550428X.2019.1647810

Day, J. K., Perez-Brumer, A., and Russell, S. T. (2018). Safe schools? Transgender youth's school experiences and perceptions of school climate. J. Youth Adolesc. 47, 1731-1742. doi: 10.1007/s10964-018-0866-x 
DePalma, R., and Atkinson, E. (2006). The sound of silence: talking about sexual orientation and schooling. Sex Educ. 6, 333-349. doi: $10.1080 / 14681810600981848$

DePalma, R., and Atkinson, E. (2009a). 'No Outsiders': moving beyond a discourse of tolerance to challenge heteronormativity in primary schools. Br. Educ. Res. J. 35, 837-855. doi: 10.1080/01411920802688705

DePalma, R., and Atkinson, E. (2009b). "Permission to talk about it": narratives of sexual equality in the primary classroom. Qual. Inq. 15, 876-892. doi: $10.1177 / 1077800409332763$

Depalma, R., and Atkinson, E. (2010). The nature of institutional heteronormativity in primary schools and practice-based responses. Teach. Teach. Educ. 26, 1669-1676. doi: 10.1016/j.tate.2010.06.018

DePalma, R., and Jennett, M. (2010). Homophobia, transphobia and culture: deconstructing heteronormativity in English primary schools. Intercult. Educ. 21, 15-26. doi: 10.1080/14675980903491858

Department of Education (2019). Relationships Education, Relationships and Sex Education (RSE) and Health Education. Department of Education. Available online at: https://assets.publishing.service.gov.uk/government/uploads/ system/uploads/attachment_data/file/805781/Relationships_Education_ Relationships_and_Sex_Education_RSE_and_Health_Education.pdf (accessed May 19, 2020).

Durwood, L., McLaughlin, K. A., and Olson, K. R. (2017). Mental health and selfworth in socially transitioned transgender youth. J. Am. Acad. Child Adolesc. Psychiatry 56, 116-123.e2. doi: 10.1016/j.jaac.2016.10.016

Education Authority Northern Ireland (2019). Guidance for Schools, EOTAS Centres and Youth Service on Supporting Transgender Young People. Northern Ireland: Education Authority. Available at: https://www.eani.org.uk/sites/ default/files/2019-10/EA\%20Guidance\%20on\%20supporting\%20transgender \%20young\%20people_FINALFINAL_24.10.19.pdf (accessed May 24, 2020).

Ehrensaft, D. (2012). From gender identity disorder to gender identity creativity: true gender self child therapy. J. Homosex 59, 337-356. doi: 10.1080/00918369.2012.653303

Ehrensaft, D. (2016). The Gender Creative Child: Pathways for Nurturing and Supporting Children Who Live Outside Gender Boxes. New York, NY: The Experiment.

Ehrensaft, D., Giammattei, S. V., Storck, K., Tishelman, A. C., and Keo-Meier, C. (2018). Prepubertal social gender transitions: What we know; what we can learn-a view from a gender affirmative lens. Int. J. Transgenderism 19, 251-268. doi: 10.1080/15532739.2017.1414649

Equaliteach (2020). Free to Be: Embedding LGBT+ Equality and Tackling Homophobic, Biphobic and Transphobic Bullying in Primary Schools. Cambridgeshire: EqualiTeach CIC. Available online at: https://equaliteach.co. uk/wp-content/uploads/FREE-TO-BE-rev4.pdf (accessed May 24, 2020).

Fast, A. A., and Olson, K. R. (2018). Gender development in transgender preschool children. Child Dev. 89, 620-637. doi: 10.1111/cdev.12758

Fayles, C. (2018). Transgender Students School Perceptions Experiences. Austin, TX: Austin Independent School District. Available online at: https://www. austinisd.org/sites/default/files/dre-surveys/17.32_transgender_students_ school_perceptions_experiences.pdf (accessed May 26, 2020).

Formby, E. (2015). Limitations of focussing on homophobic, biphobic and transphobic 'bullying' to understand and address LGBT young people's experiences within and beyond school. Sex Educ. 15, 626-640. doi: $10.1080 / 14681811.2015 .1054024$

Frohard-Dourlent, H. (2016). 'I don't care what's under your clothes': the discursive positioning of educators working with trans and gender-nonconforming students. Sex Educ. 16, 63-76. doi: 10.1080/14681811.2015.1022819

Frohard-Dourlent, H. (2018). “The student drives the car, right?": trans students and narratives of decision-making in schools. Sex Educ. 18, 328-344. doi: 10.1080/14681811.2017.1393745

Gill-Peterson, J. (2018). Histories of the Transgender Child. Chicago, IL: University of Minnesota Press.

Gonzalez, M., and McNulty, J. (2010). Achieving competency with transgender youth: school counselors as collaborative advocates. J. LGBT Issues Couns. 4, 176-186. doi: 10.1080/15538605.2010.524841

Grant, C., and Zwier, E. (2011). Intersectionality and student outcomes: sharpening the struggle against racism, sexism, classism, ableism, heterosexism, nationalism, and linguistic, religious, and geographical discrimination in teaching and learning. Multicult. Perspect. 13, 181-188. doi: $10.1080 / 15210960.2011 .616813$
Greytak, E. A., Kosciw, J. G., and Boesen, M. J. (2013). Putting the "T" in "resource": the benefits of LGBT-related school resources for transgender youth. J. LGBT Youth 10, 45-63. doi: 10.1080/19361653.2012.718522

Greytak, E. A., Kosciw, J. G., and Diaz, E. M. (2009). Harsh Realities: The Experiences of Transgender Youth in Our Nation's Schools. Gay, Lesbian and Straight Education Network (GLSEN). Available online at: https://eric.ed.gov/? id=ED505687 (accessed March 11, 2020).

Grossman, A. H., Haney, A. P., Edwards, P., Alessi, E. J., Ardon, M., and Howell, T. J. (2009). Lesbian, gay, bisexual and transgender youth talk about experiencing and coping with school violence: a qualitative study. J. LGBT Youth 6, 24-46. doi: $10.1080 / 19361650802379748$

Hendricks, M. L., and Testa, R. J. (2012). A conceptual framework for clinical work with transgender and gender nonconforming clients: an adaptation of the minority stress model. Prof. Psychol. Res. Pract. 43, 460-467. doi: 10.1037/a0029597

Herriot, L., Burns, D. P., and Yeung, B. (2018). Contested spaces: trans-inclusive school policies and parental sovereignty in Canada. Gend. Educ. 30, 695-714. doi: 10.1080/09540253.2017.1396291

Hidalgo, M. A., Ehrensaft, D., Tishelman, A. C., Clark, L. F., Garofalo, R., Rosenthal, S. M., et al. (2013). The gender affirmative model: what we know and what we aim to learn. Hum. Dev. 56, 285-290. doi: 10.1159/0003 55235

Hill, D. B., and Menvielle, E. (2009). "You have to give them a place where they feel protected and safe and loved": the views of parents who have gender-variant children and adolescents. J. LGBT Youth 6, 243-271. doi: $10.1080 / 19361650903013527$

Human Rights Campaign (2014). Supporting and Caring for Our Gender Expansiven Youth. Human Rights Campaign. Available online at: https:// assets2.hrc.org/files/assets/resources/Gender-expansive-youth-report-final. pdf?_ga $=2.251823242 .2087749765 .1590348127-1925934252.1590348127$ (accessed May 24, 2020).

Human Rights Campaign (2018). Gender Expansive Youth Report. Human Rights Campaign. Available online at: https://assets2.hrc.org/files/assets/resources/ GEreport1.pdf?_ga=2.43094310.261715642.1590513884-1925934252. 1590348127 (accessed May 26, 2020).

Ingrey, J. (2018). Problematizing the cisgendering of school washroom space: interrogating the politics of recognition of transgender and gender nonconforming youth. Gend. Educ. 30, 1-16. doi: 10.1080/09540253.2018.1483492

Iskander, L., and Shabtay, A. (2018). Who runs the schools?: LGBTQ youth activism and Ontario's Bill 13. J. LGBT Youth 15, 1-14. doi: 10.1080/19361653.2018.1500508

ITHF (2019). Transgender Research Informed Consent (TRICON) Disclosure Policy. International Transgender Health Forum. Available online at: https://www. facebook.com/groups/transgenderhealth (accessed May 25, 2020).

Johnson, C. W., Singh, A. A., and Gonzalez, M. (2014). "It's complicated": collective memories of transgender, queer, and questioning youth in high school. J. Homosex. 61, 419-434. doi: 10.1080/00918369.2013.842436

Jones, T., and Hillier, L. (2013). Comparing trans-spectrum and same-sex-attracted youth in Australia: increased risks, increased activisms. J. LGBT Youth 10, 287-307. doi: 10.1080/19361653.2013.825197

Jones, T., Smith, E., Ward, R., Dixon, J., Hillier, L., and Mitchell, A. (2016). School experiences of transgender and gender diverse students in Australia. Sex Educ. 16, 156-171. doi: 10.1080/14681811.2015.1080678

Kahn, L. G., and Lindstrom, L. (2015). "I just want to be myself": adolescents with disabilities who identify as a sexual or gender minority. Educ. Forum 79, 362-376. doi: 10.1080/00131725.2015.1068416

Katz-Wise, S. L., Ehrensaft, D., Vetters, R., Forcier, M., and Austin, S. B. (2018). Family functioning and mental health of transgender and gendernonconforming youth in the trans teen and family narratives project. J. Sex Res. 55, 582-590. doi: 10.1080/00224499.2017.1415291

Kearns, L.-L., Mitton-Kukner, J., and Tompkins, J. (2017). Transphobia and cisgender privilege: pre-service teachers recognizing and challenging gender rigidity in schools. Can. J. Educ. Can. Léduc. 40, 1-27. Retrieved from: https://journals.sfu.ca/cje/index.php/cje-rce/article/view/2367 (accessed April 26, 2020).

Kennedy, N. (2013). Cultural cisgenderism: consequences of the imperceptible. $B r$. Psychol. Women Section Rev. 15.2.

Kennedy, N. (2018). "Prisoners of Lexicon: cultural cisgenderism and transgender children," in Normed Children: Effects of Gender and Sex Related Normativity 
on Childhood and Adolescence, eds E. Schneider and C. Balthes-Löhr (Bielefeld: Transcript Verlag), 297-312.

Keo-Meier, C., and Ehrensaft, D. (2018). The Gender Affirmative Model: An Interdisciplinary Approach to Supporting Transgender and Gender Expansive Children. Washington, DC: American Psychological Association. Available online at: https://www.apa.org/pubs/books/4317487 (accessed October 17, 2019).

Kjaran, J. I., and Jóhannesson, I. Á. (2013). Manifestations of Heterosexism in Icelandic upper secondary schools and the responses of LGBT students. J. LGBT Youth 10, 351-372. doi: 10.1080/19361653.2013.824373

Klein, A., and Golub, S. A. (2016). Family rejection as a predictor of suicide attempts and substance misuse among transgender and gender nonconforming adults. LGBT Health 3, 193-199. doi: 10.1089/lgbt.2015.0111

Kosciw, J. G., Greytak, E. A., Bartkiewicz, M. J., Boesen, M. J., Palmer, N. A., and Gay, L. S. E. N. (GLSEN) (2012). The 2011 National School Climate Survey The Experiences of Lesbian, Gay, Bisexual and Transgender Youth in Our Nation's Schools. New York, NY: ERIC Clearinghouse.

Kosciw, J. G., Greytak, E. A., Giga, N. M., Villenas, C., and Danischewski, D. J. (2016). The 2015 National School Climate Survey: The Experiences of Lesbian, Gay, Bisexual, Transgender, and Queer Youth in Our Nation's Schools. New York, NY: GLSEN. Available online at: https://www.glsen.org/sites/default/ files/2019-10/GLSEN\%202015\%20National\%20School\%20Climate\%20Survey \%20\%28NSCS\%29\%20-\%20Executive\%20Summary.pdf (accessed March 10, 2020).

Kosciw, J. G., Greytak, E. A., Zongrone, A. D., Clark, C. M., Truong, N. L., and Gay, L. S. E. N. (GLSEN) (2018). The 2017 National School Climate Survey: The Experiences of Lesbian, Gay, Bisexual, Transgender, and Queer Youth in Our Nation's Schools. New York, NY: Gay, Lesbian and Straight Education Network (GLSEN).

Kosciw, J. G., Palmer, N. A., Kull, R. M., and Greytak, E. A. (2013). The Effect of Negative School Climate on Academic Outcomes for LGBT Youth and the role of in-school supports. J. Sch. Violence 12, 45-63. doi: $10.1080 / 15388220.2012 .732546$

Kosciw, J. G., and Pizmony-Levy, O. (2016). International perspectives on homophobic and transphobic bullying in schools. J. LGBT Youth 13, 1-5. doi: 10.1080/19361653.2015.1101730

Kuvalanka, K. A., Newsome, W. S., Letiecq, B. L., Neff, J., Neubeiser, K., Snodgrass, J., et al. (2019). Grandmothers raising their transgender grandchildren: an exploratory study. J. GLBT Fam. Stud. 16, 1-18. doi: 10.1080/1550428X.2019.1630883

Kuvalanka, K. A., Weiner, J. L., and Mahan, D. (2014). Child, family, and community transformations: findings from interviews with mothers of transgender girls. J. GLBT Fam. Stud. 10, 354-379. doi: 10.1080/1550428X.2013.834529

Leeds City Council (2018). Guidance on Supporting Children and Young People who are Trans or Who Are Questioning Their Gender Identity for All Schools and Children and Families Services Settings. Leeds: Leeds City Council. Available online at: https://leedschildcare.proceduresonline.com/pdfs/gender. pdf (accessed May, 24, 2020).

LGBT Youth Scotland (2017). Supporting Transgender Young People: Guidance for Schools in Scotland. LGBT Youth Scotland. Available online at: https:// www.lgbtyouth.org.uk/media/1344/supporting-transgender-young-people. pdf (accessed May, 24, 2020).

LGBT Youth Scotland (2019). Life for LGBT Young People in Dumfries and Galloway, Schools Survey 2019. Edinburgh.

Lopez, X., Marinkovic, M., Eimicke, T., Rosenthal, S. M., Olshan, J. S., and Pediatric Endocrine Society Transgender Health Special Interest Group (2017). Statement on gender-affirmative approach to care from the pediatric endocrine society special interest group on transgender health. Curr. Opin. Pediatr. 29, 475-480. doi: 10.1097/MOP.0000000000000516

Luecke, J. C. (2018). The gender facilitative school: Advocating authenticity for gender expansive children in pre-adolescence. Improv. Sch. 21, 269-284. doi: $10.1177 / 1365480218791881$

Malins, P. (2016). How inclusive is "inclusive education" in the Ontario elementary classroom?: teachers talk about addressing diverse gender and sexual identities. Teach. Teach. Educ. 54, 128-138. doi: 10.1016/j.tate.2015.11.004

Martino, W., and Cumming-Potvin, W. (2016). Teaching about sexual minorities and "princess boys": a queer and trans-infused approach to investigating
LGBTQ-themed texts in the elementary school classroom. Discourse Stud. Cult. Polit. Educ. 37, 807-827. doi: 10.1080/01596306.2014.940239

Martino, W., and Cumming-Potvin, W. (2017). Effeminate arty boys and butch soccer girls': investigating queer and trans-affirmative pedagogies under conditions of neoliberal governance. Res. Pap. Educ. 34, 131-152. doi: 10.1080/02671522.2017.1402082

Martino, W., and Cumming-Potvin, W. (2018). Transgender and gender expansive education research, policy and practice: reflecting on epistemological and ontological possibilities of bodily becoming. Gend. Educ. 30, 687-694. doi: $10.1080 / 09540253.2018 .1487518$

Marx, R. A., and Kettrey, H. H. (2016). Gay-straight alliances are associated with lower levels of school-based victimization of LGBTQ+ Youth: a systematic review and meta-analysis. J. Youth Adolesc. 45, 1269-1282. doi: 10.1007/s10964-016-0501-7

Marx, R. A., Roberts, L. M., and Nixon, C. T. (2017). When care and concern are not enough: school personnel's development as allies for trans and gender non-conforming students. Soc. Sci. 6, 1-11. doi: 10.3390/socsci6010011

Mayo, J. B. (2007). Negotiating sexual orientation and classroom practice(s) at school. Theory Res. Soc. Educ. 35, 447-464. doi: 10.1080/00933104.2007.10473344

McBride, R.-S. (2020). A literature review of the secondary school experiences of trans youth. J. LGBT Youth 1-32. doi: 10.1080/19361653.2020.1727815

McGuire, J. K., Anderson, C. R., Toomey, R. B., and Russell, S. T. (2010). School climate for transgender youth: a mixed method investigation of student experiences and school responses. J. Youth Adolesc. 39, 1175-1188. doi: 10.1007/s10964-010-9540-7

Menvielle, E. (2012). A comprehensive program for children with gender variant behaviors and gender identity disorders. J. Homosex. 59, 357-368. doi: 10.1080/00918369.2012.653305

Meyer, E. J., and Keenan, H. (2018). Can policies help schools affirm gender diversity? A policy archaeology of transgender-inclusive policies in California schools. Gend. Educ. 30, 736-753. doi: 10.1080/09540253.2018.14 83490

Meyer, E. J., and Leonardi, B. (2018). Teachers' professional learning to affirm transgender, non-binary, and gender-creative youth: experiences and recommendations from the field. Sex Educ. 18, 449-463. doi: $10.1080 / 14681811.2017 .1411254$

Meyer, E. J., and Stader, D. (2009). Queer youth and the culture wars: from classroom to courtroom in Australia, Canada and the United States. J. LGBT Youth 6, 135-154. doi: 10.1080/19361650902905624

Meyer, E. J., Tilland-Stafford, A., and Airton, L.. (2016). Transgender and gendercreative students in PK-12 schools: what we can learn from their teachers. Teach. Coll. Record 118, 1-50.

Meyer, I. H. (2003). Prejudice, social stress, and mental health in lesbian, gay, and bisexual populations: conceptual issues and research evidence. Psychol. Bull. 129, 674-697. doi: 10.1037/0033-2909.129.5.674

Miller, S. J. (ed.). (2016a). Teaching, Affirming, and Recognizing Trans and Gender Creative Youth: A Queer Literacy Framework. New York, NY: Palgrave Macmillan US.

Miller, S. J. (ed.). (2016b). "The nonconclusion: trans*ing education into the future-this cannot wait," in Teaching, Affirming, and Recognizing Trans and Gender Creative Youth (New York, NY: Queer Studies and Education; Palgrave Macmillan), 293-297. doi: 10.1057/978-1-137-56766-6_16

Miller, S. J. (ed.). (2016c). "Why a queer literacy framework matters: models for sustaining (a)gender self-determination and justice in today?s schooling practices," in Teaching, Affirming, and Recognizing Trans and Gender Creative Youth (New York, NY: Queer Studies and Education; Palgrave Macmillan), 25-45. doi: 10.1057/978-1-137-56766-6_2

Miller, S. J., Mayo, C., and Lugg, C. A. (2018). Sex and gender in transition in US schools: ways forward. Sex Educ. 18, 345-359. doi: $10.1080 / 14681811.2017 .1415204$

Mitchell, M., Gray, M., and Beninger, K. (2014). Tackling Homophobic, Biphobic and Transphobic Bullying Among School-Aged Children and Young People: Findings From a Mixed Methods Study of Teachers, Other Providers and Pupils. London: Government Equalities Office.

Mitchell, M., Kotecha, M., Davies, M., Porter, H., and Turley, C. (2016). Evaluation of an Anti-Homophobic, Biphobic and Transphobic (HB\&T) Bullying Programme. National Centre for Social Research. Available online 
at: http://natcen.ac.uk/media/1216039/natcens-independent-evaluation-ofan-anti-hbt-bullying-programme_research-report.pdf

Mulcahy, M., Dalton, S., Kolbert, J., and Crothers, L. (2016). Informal mentoring for lesbian, gay, bisexual, and transgender students. J. Educ. Res. 109, 405-412. doi: 10.1080/00220671.2014.979907

Murchison, G., Adkins, D., Conard, L. A., Ph, R., Ehrensaft, D., Elliott, T., et al. (2016). Supporting \& Caring for Transgender Children'. Human Rights Campaign. Available online at: https://www.hrc.org/resources/supportingcaring-for-transgender-children/ (accessed October 3, 2019).

National Education Union (2018). Supporting Trans and Gender-Questioning Students. National Education Union. Available online at: https://neu.org.uk/ media/1836/view (accessed May 24, 2020).

Neary, A. (2019). Complicating constructions: middle-class parents of transgender and gender-diverse children. J. Fam. Stud. 1-17. doi: $10.1080 / 13229400.2019 .1650799$

Neary, A., and Cross, C. (2018). Exploring Gender Identity and Gender Norms in Primary Schools: The Perspectives of Educators and Parents of Transgender and Gender Variant Children. Limerick: University of Limerick and the Transgender Equality Network of Ireland. Available online at: https://core.ac. uk/download/pdf/159405378.pdf (accessed May 26, 2020).

Newbury, P. (2013). Disrupting the Politics of Etiquette. Available online at: https://cisnormativity.wordpress.com/2013/08/17/disrupting-the-politicsof-etiquette/ (accessed August 30, 2019).

Newhook, J. T., Pyne, J., Winters, K., Feder, S., Holmes, C., Tosh, J., et al. (2018a). A critical commentary on follow-up studies and "desistance" theories about transgender and gender-nonconforming children. Int. J. Transgenderism 19, 212-224. doi: 10.1080/15532739.2018.1456390

Newhook, J. T., Winters, K., Pyne, J., Jamieson, A., Holmes, C., Feder, S., et al. (2018b). Teach your parents and providers well. Can. Fam. Physician $64,332-335$.

O'Flynn, S. (2016). 'Oh yeah - is she a he-she?' Female to male transgendered pupils in the formal and informal cultures of an English secondary school. Pedagogy Cult. Soc. 24, 431-444. doi: 10.1080/14681366.2016.119 4311

Oliphant, J., Veale, J., Macdonald, J., Carroll, R., Johnson, R., Harte, M., et al. (2018). Guidelines for Gender Affirming Healthcare for Gender Diverse and Transgender Children, Young People and Adults in Aotearoa New Zealand. Available online at: https://researchcommons.waikato.ac.nz/handle/ 10289/12160 (accessed October 3, 2019).

Olson, K. R. (2016). Prepubescent transgender children: what we do and do not know. J. Am. Acad. Child Adolesc. Psychiatry 55, 155-156.e3. doi: 10.1016/j.jaac.2015.11.015

Olson, K. R., and Enright, E. A. (2018). Do transgender children (gender) stereotype less than their peers and siblings? Dev. Sci. 21:e12606. doi: 10.1111/desc. 12606

Olson, K. R., and Gülgöz, S. (2018). Early findings from the transyouth project: gender development in transgender children. Child Dev. Perspect. 12, 93-97. doi: 10.1111/cdep.12268

Olson, K. R., Key, A. C., and Eaton, N. R. (2015). Gender cognition in transgender children. Psychol. Sci. 26, 467-474. doi: 10.1177/0956797614568156

Omercajic, K. (2015). Investigating trans-affirmative education policies and practices in Ontario (Electron. Thesis Diss. Repos). Available online at: https://ir.lib.uwo. ca/etd/3162

Omercajic, K., and Martino, W. (2020). Supporting transgender inclusion and gender diversity in schools: a critical policy analysis. Front. Sociol. 5:27. doi: $10.3389 /$ fsoc. 2020.00027

Palkki, J., and Caldwell, P. (2018). "We are often invisible": a survey on safe space for LGBTQ students in secondary school choral programs. Res. Stud. Music Educ. 40, 28-49. doi: 10.1177/1321103X17734973

Parsons, L. T. (2016). Learning from preservice teachers' responses to trans-themed young adult literature: improving personal practice in teacher education. Discourse Stud. Cult. Polit. Educ. 37, 933-947. doi: 10.1080/01596306.2015.1084105

Payne, E., and Smith, M. J. (2014). The big freak out: educator fear in response to the presence of transgender elementary school students. J. Homosex. 61, 399-418. doi: 10.1080/00918369.2013.842430

Pennell, S. M. (2016a). Queer cultural capital: implications for education. Race Ethn. Educ. 19, 324-338. doi: 10.1080/13613324.2015.1013462
Pennell, S. M. (2016b). "Transitional memoirs: reading using a queer cultural capital model," in Teaching, Affirming, and Recognizing Trans and Gender Creative Youth: A Queer Literacy Framework Queer Studies and Education, ed S. J. Miller (New York, NY: Palgrave Macmillan US), 199-230.

Peter, T., Taylor, C., and Campbell, C. (2016). "You can't break... when you're already broken": the importance of school climate to suicidality among LGBTQ youth. J. Gay Lesbian Ment. Health 20, 195-213. doi: $10.1080 / 19359705.2016 .1171188$

Poteat, V., Calzo, J., and Yoshikawa, H. (2018). Gay-straight alliance involvement and youths' participation in civic engagement, advocacy, and awarenessraising. J. Appl. Dev. Psychol. 56, 13-20. doi: 10.1016/j.appdev.2018.01.001

Poteat, V., and Espelage, D. (2007). Predicting psychosocial consequences of homophobic victimization in middle school students. J. Early Adolesc. 27, 175-191. doi: 10.1177/0272431606294839

Poteat, V. P., Heck, N. C., Yoshikawa, H., and Calzo, J. P. (2016). Greater engagement among members of gay-straight alliances: individual and structural contributors. Am. Educ. Res. J. 53, 1732-1758. doi: 10.3102/0002831216674804

Pullen Sansfaçon, A., Medico, D., Suerich-Gulick, F., and Newhook, J. T. (2020). "I knew that I wasn't cis, I knew that, but I didn't know exactly”: Gender identity development, expression and affirmation in youth who access gender affirming medical care. Int. J. Transgender Health 21, 307-320.

Pullen Sansfaçon, A., Robichaud, M.-J., and Dumais-Michaud, A.-A. (2015). The experience of parents who support their children's gender variance. J. LGBT Youth 12, 39-63. doi: 10.1080/19361653.2014.935555

Pyne, J. (2014). The governance of gender non-conforming children: a dangerous enclosure. Ann. Rev. Critic. Psychol. 11, 79-96.

Rae, J. R., Gülgöz, S., Durwood, L., DeMeules, M., Lowe, R., Lindquist, G., et al. (2019). Predicting early-childhood gender transitions. Psychol. Sci. 30, 669-681. doi: $10.1177 / 0956797619830649$

Rafferty, J., Committee on Psychosocial Aspects of Child and Family Health, Committee on Adolescence, and Section on Lesbian, Gay, Bisexual, and Transgender Health and Wellness (2018). Ensuring comprehensive care and support for transgender and gender-diverse children and adolescents. Pediatrics 142:e20182162. doi: $10.1542 /$ peds.2018-2162

Rahilly, E. P. (2015). The gender binary meets the gender-variant child: parents' negotiations with childhood gender variance. Gend. Soc. 29, 338-361. doi: 10.1177/0891243214563069

Rands, K. E. (2009). Considering transgender people in education: a gender-complex approach. J. Teach. Educ. 60, 419-431. doi: $10.1177 / 0022487109341475$

Reed, B., Reed, T., and Rhodes, S. (2010). Guidance on Combating Transphobic Bullying in Schools. GIRES. Available online at: https://www.gires.org.uk/ guidance- on-combating-transphobic-bullying-in-schools/ (accessed May 24, 2020).

Riggs, D. W., and Bartholomaeus, C. (2018). Cisgenderism and certitudeparents of transgender children negotiating educational contexts. TSQ Transgender Stud. Q. 5, 67-82. doi: 10.1215/23289252-4291529

Riley, E. A. (2012). The needs of gender-variant children and their parents (Doctoral thesis), University of Sydney, Sydney, NSW, Australia. Retrieved from: https://ses.library.usyd.edu.au/bitstream/handle/2123/8749/E_Riley_thesis_ November2012.pdf;jsessionid=9C1AAFFAA6D54BC4B336D85E9048F59E? sequence $=7$

Roberts, A. L., Rosario, M., Corliss, H. L., Koenen, K. C., and Austin, S. B. (2012). Childhood gender nonconformity: a risk indicator for childhood abuse and posttraumatic stress in youth. Pediatrics 129, 410-417. doi: 10.1542/peds.2011-1804

Roberts, G., Allan, C., and Wells, K. (2007). Understanding gender identity in K-12 schools. J. Gay Lesbian Issues Educ. 4, 119-129. doi: 10.1300/J367v04n04_08

Robinson, K., Bansel, P., Denson, N., Ovenden, G., and Davies, C. (2014). Growing Up Queer: Issues Facing Young Australians Who Are Gender Variant and Sexuality Diverse. Melbourne, VIC: Young and Well Cooperative Research Centre.

Russell, S. T., Pollitt, A. M., Li, G., and Grossman, A. H. (2018). Chosen name use is linked to reduced depressive symptoms, suicidal ideation, and suicidal behavior among transgender youth. J. Adolesc. Health Off. Publ. Soc. Adolesc. Med. 63, 503-505. doi: 10.1016/j.jadohealth.2018.02.003

Ryan, C. L., Patraw, J. M., and Bednar, M. (2013). Discussing princess boys and pregnant men: teaching about gender diversity and transgender 
experiences within an elementary school curriculum. J. LGBT Youth 10, 83-105. doi: 10.1080/19361653.2012.718540

Sadowski, M., and Jennings, K. (2016). Safe Is Not Enough: Better Schools for LGBTQ Students. Cambridge, MA: Harvard Education Press.

Schindel, J. E. (2008). Gender 101- beyond the binary: Gay-straight alliances and gender activism. Sex. Res. Soc. Policy 5:56. doi: 10.1525/srsp.2008.5.2.56

Serano, J. (2011). Whipping Girl FAQ on Cissexual. Available online at: http:// juliaserano.blogspot.com/2011/08/whipping-girl-faq-on-cissexual.html accessed 30/08/2019 (accessed August 30, 2019).

Serano, J. (2016). Whipping Girl: A Transsexual Woman on Sexism and the Scapegoating of Femininity, 2nd Edn. Berkeley, CA: Seal Press

Shelton, J. (2016). Reframing risk for transgender and gender-expansive young people experiencing homelessness. J. Gay Lesbian Soc. Serv. 28, 277-291. doi: 10.1080/10538720.2016.1221786

Shelton, S. A., and Lester, A. O. S. (2018). Finding possibilities in the impossible: a celebratory narrative of trans youth experiences in the Southeastern USA. Sex Educ. 18, 391-405. doi: 10.1080/14681811.2017.1421920

Simons, L., Schrager, S. M., Clark, L. F., Belzer, M., and Olson, J. (2013). Parental support and mental health among transgender adolescents. J. Adolesc. Health Off. Publ. Soc. Adolesc. Med. 53, 791-793. doi: 10.1016/j.jadohealth.2013.07.019

Sinclair-Palm, J., and Gilbert, J. (2018). Naming new realities: supporting trans youth in education. Sex Educ. 18, 321-327. doi: $10.1080 / 14681811.2018 .1452347$

Slesaransky-Poe, G., Ruzzi, L., Dimedio, C., and Stanley, J. (2013). Is this the right elementary school for my gender nonconforming child? J. LGBT Youth 10, 29-44. doi: 10.1080/19361653.2012.718521

Smith, M. J., and Payne, E. (2016). Binaries and biology: conversations with elementary education professionals after professional development on supporting transgender students. Educ. Forum 80, 34-47. doi: 10.1080/00131725.2015.1102367

Snapp, S., Burdge, H., Licona, A., Moody, R., and Russell, S. (2015). Students' perspectives on LGBTQ-inclusive curriculum. Equity Excell. Educ. 48, 249-265. doi: 10.1080/10665684.2015.1025614

Spack, N. P., Edwards-Leeper, L., Feldman, H. A., Leibowitz, S., Mandel, F., Diamond, D. A., et al. (2012). Children and adolescents with gender identity disorder referred to a pediatric medical center. Pediatrics 129, 418-425. doi: $10.1542 /$ peds.2011-0907

Stonewall (2018). Best Practice Guide: How Primary Schools Are Celebrating Difference and Tackling Homophobia, Biphobia and Transphobia. Stonewall. Available online at: https://www.stonewall.org.uk/system/files/stonewall_ primary_best_practice_guide_2018_-_final.pdf (accessed May 24, 2020).

Stonewall (2019). Creating an LGBT-Inclusive Primary Curriculum. Stonewall. Available online at: https://www.stonewall.org.uk/about-us/news/lgbtinclusive-curriculum-guide-launched-uk-primary-schools (accessed May 24, 2020).

Stonewall (2020). Next Steps in Inclusive Education. Stonewall. Available online at: https://www.stonewall.org.uk/system/files/next_steps_in_inclusive_ education.pdf (accessed May 24, 2020).

Taylor, C., and Peter, T. (2011). Every Class in Every School: The First National Climate Survey on Homophobia, Biphobia, and Transphobia in Canadian Schools. Final Report. Edale Canada Human Rights Trust, Toronto, ON.

Telfer, M., Tollit, M., and Feldman, D. (2015). Transformation of health-care and legal systems for the transgender population: the need for change in Australia. J. Paediatr. Child Health 51, 1051-1053. doi: 10.1111/jpc.12994

Trans Inclusion Toolkit (2019). Trans Inclusion Toolkit for Schools and Education Settings. Leicestershire Country Council; Leicester City Council; Nottinghamshire County Council; Oxfordshire County Council; Sheffield City Council; Leicester LGBT Centre; Topaz LGBT+ youth group; SEND Support. Available online at: https://www.think2speak.com/resource-library-formembers/trans-inclusion-toolkit-for-schools-and-education-settings?fbclid= IwAR1HoBPWqvgLXIW6y1WiXO8vGS7MNIvIGZv6ChOdpVnPA557Q UMIosqYkqo (accessed May 27, 2020).

Travers, R., Bauer, G., and Pyne, J. (2012). Impacts of strong parental support for trans youth: a report prepared for Children's Aid Society of Toronto and Delisle Youth Services. Trans Pulse. Available online at: http://transpulseproject.ca/ research/impacts-of-strong-parental-support-for-trans-youth (accessed April 20, 2020).

Turban, J. L. (2017). Transgender youth: the building evidence base for early social transition. J. Am. Acad. Child Adolesc. Psychiatry 56, 101-102. doi: 10.1016/j.jaac.2016.11.008

Turban, J. L., Beckwith, N., Reisner, S. L., and Keuroghlian, A. S. (2019). Association between recalled exposure to gender identity conversion efforts and psychological distress and suicide attempts among transgender adults. JAMA Psychiatry. 77, 1-9. doi: 10.1001/jamapsychiatry.2019.2285

Turban, J. L., and Ehrensaft, D. (2018). Research review: gender identity in youth: treatment paradigms and controversies. J. Child Psychol. Psychiatry 59, 1228-1243. doi: $10.1111 /$ jcpp. 12833

Turban, J. L., and Keuroghlian, A. S. (2018). Dynamic gender presentations: understanding transition and "de-transition" among transgender youth. J. Am. Acad. Child Adolesc. Psychiatry 57, 451-453. doi: 10.1016/j.jaac.2018.03.016

Ullman, J. (2014). Ladylike/butch, sporty/dapper: exploring "gender climate" with Australian LGBTQ students using stage-environment fit theory. Sex Educ. 14, 430-443. doi: 10.1080/14681811.2014.919912

Ullman, J. (2015a). 'At-risk' or school-based risk? Testing a model of school-based stressors, coping responses, and academic self-concept for same-sex attracted youth. J. Youth Stud. 18, 417-433. doi: 10.1080/13676261.2014.963539

Ullman, J. (2015b). Free to Be? Exploring the Schooling Experiences of Australia's Sexuality and Gender Diverse Secondary School Students. Penrith, NSW: Centre for Educational Research, Western Sydney University.

Ullman, J. (2017). Teacher positivity towards gender diversity: exploring relationships and school outcomes for transgender and gender-diverse students. Sex Educ. 17, 276-289. doi: 10.1080/14681811.2016.1273104

Ullman, J., and Ferfolja, T. (2015). Bureaucratic constructions of sexual diversity: 'sensitive', 'controversial' and silencing. Teach. Educ. 26, 145-159. doi: 10.1080/10476210.2014.959487

UNDESA (2013). Youth Definition Fact Sheet. Available online at: https://www.un. org/esa/socdev/documents/youth/fact-sheets/youth-definition.pdf (accessed May 25, 2020).

UNESCO (2016). Out in the Open: Education Sector Responses to Violence Based on Sexual Orientation and Gender Identity/Expression. UNESCO. Available online at: http://proxy.library.carleton.ca/loginurl=https://www.deslibris.ca/ ID/10062639 (accessed October 18, 2019).

Vincent, B. W. (2018). Studying trans: recommendations for ethical recruitment and collaboration with transgender participants in academic research. Psychol. Sex. 9, 102-116. doi: 10.1080/19419899.2018.1434558

Wernick, L. J., Kulick, A., and Inglehart, M. H. (2014). Influences of peers, teachers, and climate on students' willingness to intervene when witnessing anti-transgender harassment. J. Adolesc. 37, 927-935. doi: 10.1016/j.adolescence.2014.06.008

Whyatt-Sames, J. (2017). Being brave: negotiating the path of social transition with a transgender child in foster care. J. GLBT Fam. Stud. 13, 309-332. doi: 10.1080/1550428X.2016.1241167

Woolley, S. W. (2017). Contesting silence, claiming space: gender and sexuality in the neo-liberal public high school. Gend. Educ. 29, 84-99. doi: $10.1080 / 09540253.2016 .1197384$

Disclaimer: The name Cal Horton is a pseudonym, the author is using this for child protection reasons. The identify of the author is known to the publisher. The editor and reviewers agree to the use of the pseudonym in this instance.

Conflict of Interest: The author declares that the research was conducted in the absence of any commercial or financial relationships that could be construed as a potential conflict of interest.

Copyright (C) 2020 Horton. This is an open-access article distributed under the terms of the Creative Commons Attribution License (CC BY). The use, distribution or reproduction in other forums is permitted, provided the original author(s) and the copyright owner(s) are credited and that the original publication in this journal is cited, in accordance with accepted academic practice. No use, distribution or reproduction is permitted which does not comply with these terms. 